\title{
Validation of 123 names of new diatom taxa from Lake Baikal
}

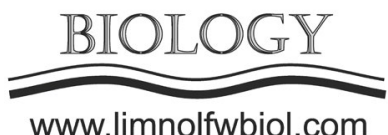

\author{
Pomazkina G.V., Rodionova E.V., Sherbakova T.A.*
}

Limnological Institute of the Siberian Branch of the Russian Academy of Sciences, Ulan-Batorskaya 3, 664033 Irkutsk, Russia.

\begin{abstract}
The monograph "Benthic diatom algae of the family Naviculaceae of Lake Baikal: Atlas and Key" by Pomazkina et al., published in 2018, in Russian, included 123 diatom taxa new to science along with well-known species. The new names were lacking descriptions in English or Latin and thus not in line with ICN. Herein English descriptions for 123 new species and intraspecific taxa are presented to validate new names for baikalian diatom algae.
\end{abstract}

Keywords: names, new benthic Bacillariophyta, validation, Lake Baikal

\section{Introduction}

The book "Benthic diatom algae of the family Naviculaceae of Lake Baikal: Atlas and Key" by G.V.Pomazkina, E.V.Rodionova \& T.A. Sherbakova (in Russian), pp. 315, released in 2018 by "Nauka" (Novosibirsk, Russia), extends the series of "Guides and Keys to Identification of Fauna and Flora of Lake Baikal". The monograph is documenting the diversity of five genera within the family Naviculaceae - the key group of Lake Baikal benthic diatoms. The first part includes a brief history and biogeography of the genera as well as ecological characteristics of areas of Lake Baikal littoral zone with increased diversity of Bacillariophyta especially Naviculaceae. The systematic sections include descriptions for 79 taxa of the genus Navicula, 30 of Hippodonta, 48 of Placoneis, 2 species of Petroplacus and 21 of Paraplaconeis of which 123 species are new to science including two new genera, Irkutia and Polygonaria. The name of each taxon is accompanied by synonyms (if available), complete description, location, and electron microscopic images. Since the descriptions for new species were not provided in Latin or English they were not valid according to regulations of the International Code of Nomenclature for algae, fungi, and plants (International code..., 2018). Herein English descriptions and associated information for 123 new taxa are included to validate their names.

\section{Validation}

\section{Genus Hippodonta Lange-Bertalot, Witkowski \& Metzeltin}

Hippodonta acris Pomazkina \& Sherbakova sp. nov. (Pomazkina et al., 2018, p. 25, Table 2)

Valves narrowly-rhombic with sharply rounded protracted ends. Length 21.0-21.5 $\mu \mathrm{m}$, width 4.9-5.0 $\mu \mathrm{m}$. Axial area narrow, linear. Central area forming the incomplete fascia in a form of a butterfly with 1-2 shortened central striae. Raphe filiform, straight, proximal endings with small pores weakly deflected oppositely, terminal raphe fissures elongated straight. Transapical striae in the middle of the valve slightly radiate, towards the apices becoming parallel then slightly convergent, $12-14$ in $10 \mu \mathrm{m}$.

Type :-Russia. Lake Baikal, the Olkhon Gates Strait, epilithon, st. 7, $20 \mathrm{~m}$ depth, 27 June 1997, collectorV. Votyakov (holotype: slide 0017-BK collection "Darwin initiative" housed at the Limnological Institute SB RAS, Irkutsk, Russia; isotype: slide 0017a-BK ibid.).

Hippodonta anglica Pomazkina \& Rodionova sp. nov. (Pomazkina et al., 2018, p. 27, Table 5)

Valves elliptic with sharply rounded protracted ends. Length 32.0-33.0 $\mu \mathrm{m}$, width 9.0-10.0 $\mu \mathrm{m}$. Axial area narrow, linear. Central area transapically widened with shortened striae. Raphe filiform, straight with prominent central and terminal pores. Transapical striae radiate, becoming slightly convergent towards the apices, 9-10 in $10 \mu \mathrm{m}$. Interstriae broader than striae.

*Corresponding author.

E-mail address: tsherb@lin.irk.ru (T.A. Sherbakova) 
Type :-Russia, Lake Baikal, the Olkhon Gates Strait, epilithon, st. 7, 20 m depth, 27 June 1997, collectorV. Votyakov (holotype: slide 0017-BKcollection "Darwin initiative" housed at the Limnological Institute SB RAS, Irkutsk, Russia; isotype: slide 0018-BK ibid.).

Hippodonta cryptocephala Pomazkina \& Rodionova sp. nov. (Pomazkina et al., 2018, p. 28, Table 8).

Valves narrowly-lanceolate with protracted rostrate ends. Length 24.0-25.0 $\mu \mathrm{m}$, width 6-7 $\mu \mathrm{m}$. Axial area narrow, linear. Central area slightly transapically widened with shortened striae. Raphe filiform, straight. Proximal raphe endings linear closely positioned, terminal fissures deflected unilaterally. Striae in the middle moderately radiate, towards the apices becoming slightly convergent, 13-14 in $10 \mu \mathrm{m}$.

Type :-Russia, Lake Baikal, near Baikalsk sity, silt, st. 40, $20 \mathrm{~m}$ depth, 23 June 1998, collector V. Votyakov (holotype: slide 0145-BK collection "Darwin initiative" housed at the Limnological Institute SB RAS, Irkutsk, Russia; isotype: slide 0145a-BK, ibid.).

Hippodonta dissimilis Pomazkina \& Rodionova sp. nov. (Pomazkina et al., 2018, p. 28, Table 9)

Valve elliptic-lanceolate with rounded protracted ends. Length $25.0 \mu \mathrm{m}$, width $5.0 \mu \mathrm{m}$. Axial area narrow, linear widening towards the center. Central area small elliptic with shortened striae bordering the central area. Raphe filiform, straight with small proximal pores, distal widening endings deflected to the same side. Transapical striae in the middle of the valve radiate multiseriate 10 in $10 \mu \mathrm{m}$, becoming biseriate, convergent and more denser at the apices, 14 in $10 \mu \mathrm{m}$. Terminal hyaline areas wide, convex.

Type :-Russia. Lake Baikal, southern basin, near the settlement B. Koty, epilithon, st. 1, $20 \mathrm{~m}$ depth, 22 June 1997, collector V. Votyakov (holotype: slide 0001-BK collection "Darwin initiative" housed at the Limnological Institute SB RAS, Irkutsk, Russia; isotype: slide 0001c-BK, ibid.).

Hippodonta elliptica Pomazkina \& Sherbakova sp. nov. (Pomazkina et al., 2018, p. 29, Table 11)

Valve lanceolate with broadly rounded ends. Length $14.9 \mu \mathrm{m}$, width $4.1 \mu \mathrm{m}$. Axial area linear continuously widening into the central area forming the incomplete fascia with two shortened striae. Raphe filiform, straight. Proximal and distal raphe endings weakly curved, slightly widened and insignificantly deflected unilaterally. Striae radiate at middle of the valve, slightly convergent near the apices, 14 in $10 \mu \mathrm{m}$. Interstriae broader than striae.

Type :-Russia. Lake Baikal, the Cape Rytiy, epilithon, st. 10, 20 m depth, 28 June 1997, collector V. Votyakov (holotype: slide 0033-BK collection "Darwin initiative" housed at the Limnological Institute SB RAS, Irkutsk, Russia; isotype: slide 0033c-BK, ibid.).

Hippodonta ignita Pomazkina sp. nov. (Pomazkina et al., 2018, p. 29, Table 12)

Valve rombic-lanceolate with sharply-rounded protracted ends. Valve length 18-19 $\mu \mathrm{m}$, width 4-5 $\mu \mathrm{m}$. Axial area linear wide. Central area forming the butterfly-shaped fascia continued on the margin. Raphe filiform, straight. Proximal and distal raphe endings direct with teardrop-shaped pores. Striae radiate, spaced, 11-12 in $10 \mu \mathrm{m}$. Interstriae broader than striae.

Type :-Russia. Lake Baikal, southern basin, near the settlement B. Koty, epilithon, st. 1, $20 \mathrm{~m}$ depth, 22 June 1997, collector V. Votyakov (holotype: slide 0001-BK collection "Darwin initiative" housed at the Limnological Institute SB RAS, Irkutsk, Russia; isotype: slide 0001a-BK, ibid.).

Hippodonta incrustata Pomazkina \& Rodionova sp. nov. (Pomazkina et al., 2018, p. 29, Table 13)

Valves rhombic-lanceolate with protracted ends. Valve length 10.4-12.1 $\mu \mathrm{m}$, width 3.5-3.6 $\mu \mathrm{m}$. Axial area narrow, linear. Central area forming the incomplete fascia with 2 shortened striae bordering the central area. Raphe filiform. Proximal raphe endings with pores weakly one-sided deflected, distal endings with larger pores. Transapical striae in the central part spaced, radiate, towards the apices becoming slightly convergent, 15 in $10 \mu \mathrm{m}$.

Type :-Russia. Lake Baikal, southern basin, near the settlement Kultuk, epilithon, st. 42, 13 m depth, 22 June 1998, collector V. Votyakov (holotype: slide 0132-BK collection "Darwin initiative" housed at the Limnological Institute SB RAS, Irkutsk, Russia; isotype: slide 0132a-BK, ibid.).

Hippodonta interrupta Pomazkina \& Sherbakova sp. nov. (Pomazkina et al., 2018, p. 30, Table 15)

Valve rombic-lanceolate with narrow cuneal rounded ends. Valve length 38-39 $\mu \mathrm{m}$, valve width 7-8 $\mu \mathrm{m}$. Axial area narrow, linear. Central area forming the incomplete fascia with two shortened striae bordering the central area. Raphe filiform, straight with widened proximal and distal endings. Striae coarse, radiate, slightly spaced at middle, becoming slightly convergent at apices, 9-10 in $10 \mu \mathrm{m}$. Terminal hyaline areas broad.

Type :-Russia. Lake Baikal, Anga bay, silt and sand, st. 6, $17 \mathrm{~m}$ depth, 27 June 1997, collector V. Votyakov (holotype: slide 0114-BK collection "Darwin initiative" housed at the Limnological Institute SB RAS, Irkutsk, Russia; isotype: slide 0115-BK, ibid.).

Hippodonta lepida Pomazkina \& Rodionova sp. nov. (Pomazkina et al., 2018, p. 31, Table 16)

Valve narrow elliptically-lanceolate with sharp cuneal protracted ends. Valve length $26.4 \mu \mathrm{m}$, width $4 \mu \mathrm{m}$. Axial area narrow, linear. Central area forming the wide complete fascia. Raphe filiform, straight with closely positioned proximal raphe endings, terminal fissures deflected in one side. Striae radiate, becoming slightly convergent near the apices, 6-7in $10 \mu \mathrm{m}$.

Type :-Russia. Lake Baikal, Anga bay, silt and sand, st. 6, $17 \mathrm{~m}$ depth, 27 June 1997, collector V. Votyakov (holotype: slide 0114-BK collection "Darwin initiative" housed at the Limnological Institute SB RAS, Irkutsk, Russia; isotype: slide 0115-BK, ibid.).

Hippodonta luculenta Pomazkina \& Rodionova sp. nov. (Pomazkina et al., 2018, p. 31, Table 17)

Valve linear-lanceolate with broadly rounded protracted ends. Valve length $13.7 \mu \mathrm{m}$, width $3.7 \mu \mathrm{m}$. Axial area narrow, the central area nearly indistinct. Raphe filiform, straight with widened proximal and distal endings. Striae radiate, becoming convergent towards apices, 6-7 in $10 \mu \mathrm{m}$. 
Type :-Russia. Lake Baikal, Peschanaya bay, epilithon, st. 3, $17 \mathrm{~m}$ depth, 27 June 1997, collector V. Votyakov (holotype: slide 0007-BK collection "Darwin initiative" housed at the Limnological Institute SB RAS, Irkutsk, Russia; isotype: slide 0007a-BK, ibid.).

Hippodonta navicula var. baicalensis Pomazkina \& Sherbakova var. nov. (Pomazkina et al., 2018, p. 33, Table 21)

Valves lanceolate with obtusely rounded ends. Valve length 16-17 $\mu \mathrm{m}$, width 3-4 $\mu \mathrm{m}$. Axial area narrow, the central area small rounded with shortened striae. Raphe filiform Straight. Proximal raphe endings with teardrop-shaped pores, distally the raphe ends with long fissures. Both endings slightly deflected into the same side. Striae strongly radiate in the middle of the valve, becoming convergent towards apices, 11-12 in $10 \mu \mathrm{m}$. Interstriae in the center broader than striae, closer to apices becoming narrower.

Type :-Russia. Lake Baikal, near the settlement M. Goloustnoe, epilithon, st. 2, $20 \mathrm{~m}$ depth, 26 June1997, collector V. Votyakov (holotype: slide 0003-BK collection "Darwin initiative" housed at the Limnological Institute SB RAS, Irkutsk, Russia; isotype: slide 0003c-BK, ibid.).

Hippodonta parva Pomazkina \& Sherbakova sp. nov. (Pomazkina et al., 2018, p. 33, Table 22)

Valve lanceolate with broadly rounded ends. Valve length $10 \mu \mathrm{m}$, width $4.3 \mu \mathrm{m}$. Axial area narrow gradually turns into the central area forming the butterfly -shaped fascia continued on the margin. Raphe filiform, straight. Proximal and distal raphe endings slightly widened subtly deflected to the same side. Striae radiate becoming convergent at the apices, 10 in $10 \mu \mathrm{m}$.

Type :-Russia. Lake Baikal, the Cape Krestovskiy, stones and silt, st. 5, 20 m depth, 27 June1997, collector V. Votyakov (holotype: slide 0012-BK collection "Darwin initiative" housed at the Limnological Institute SB RAS, Irkutsk, Russia; isotype: slide 0013-BK, ibid.).

Hippodonta peculiaris Pomazkina \& Rodionova sp. nov. (Pomazkina et al., 2018, p. 34, Table 23)

Valve lanceolate with protracted cuneal ends. Valve length $41.0 \mu \mathrm{m}$, width $10.7 \mu \mathrm{m}$. Axial area linear gradually turns into the oval central area forming broad fascia with shortened striae. Raphe filiform, straight. Proximal and distal raphe endings direct with elongated teardrop-shaped fissures. Proximal raphe ends very distant. Striae radiate, convergent at the apices, 12 in $10 \mu \mathrm{m}$.

Type :-Russia. Lake Baikal, the Cape Krestovskij, stones and silt, st. 5, $20 \mathrm{~m}$ depth, 27 June1997, collector V. Votyakov (holotype: slide 0012-BK collection "Darwin initiative" housed at the Limnological Institute SB RAS, Irkutsk, Russia; isotype: slide 0012c-BK, ibid.).

Hippodonta rostellata Pomazkina \& Rodionova sp. nov. (Pomazkina et al., 2018, p. 34, Table 24)

Valve lanceolate with protracted sharply rounded ends. Valve length $52.4 \mu \mathrm{m}$, width $9.0 \mu \mathrm{m}$. Axial area linear gradually widening turns into the apically elongated oval central area. Raphe broad, straight. Proximal raphe endings elongated widened direct, distal ends teardrop-shaped subtly deflected to the same side. Striae radiate in the center, spaced, 10 in $10 \mu \mathrm{m}$, becoming convergent and denser towards apices, 12 in $10 \mu \mathrm{m}$.

Type :-Russia, Lake Baikal, the northern basin, near the Cape Kabanij, epilithon, st. 22, 20 m depth, 04 July 1997, collector V. Votyakov (holotype: slide 0073-BK collection "Darwin initiative" housed at the Limnological Institute SB RAS, Irkutsk, Russia; isotype: slide 0073a-BK, ibid.).

Hippodonta scalpelliformis Pomazkina \& Sherbakova sp. nov. (Pomazkina et al., 2018, p. 34, Table 25)

Valve lanceolate with broadly rounded ends. Valve length $10.9 \mu \mathrm{m}$, width $3.2 \mu \mathrm{m}$. Axial area linear gradually widening and turns into the small central area with 2 shortened striae. Raphe filiform, straight with teardrop-shaped widenings of proximal and distal raphe endings. Striae radiate biseriate, becoming slightly convergent at apices, 7-8 in $10 \mu \mathrm{m}$.

Type :- Lake Baikal, the Cape Rytyi, epilithon, st. 10, 20 m depth, 28 June 1997, collector V. Votyakov (holotype: slide 0033-BK collection "Darwin initiative" housed at the Limnological Institute SB RAS, Irkutsk, Russia; isotype: slide 0034-BK, ibid.).

Hippodonta subsalsa (Grunow) Pomazkina \& Rodionova comb. nov. \& stat. nov. (Pomazkina et al., 2018, p. 35, Table 27)

Basionym: Navicula tumida var. subsalsa Grunow 1860: 537, pl. 2: figs 43 b, c

Synonym: Navicula anglica var. subsalsa (Grunow) Cleve 1895: 22

Valve elliptically-lanceolate with cuneal broadly rounded ends. Valve length $34.0 \mu \mathrm{m}$, width $7.5 \mu \mathrm{m}$. Axial area linear, central area oval with shortened striae. Raphe filiform, straight with widening proximal and distal raphe endings. Striae radiate, becoming parallel then slightly convergent at apices, 11-12 in 10 $\mu \mathrm{m}$.

Hippodonta tenuis Pomazkina \& Sherbakova sp. nov. (Pomazkina et al., 2018, p. 36, Table 28)

Valve rhombic-lanceolate with protracted sharply rounded ends. Valve length $30.0 \mu \mathrm{m}$, width 4.8 $\mu \mathrm{m}$. Axial area broad, the central area transapically widening forming incomplete fascia with shortened striae. Raphe filiform, straight with small widening of proximal and distal raphe endings. Striae radiate becoming slightly parallel at apices, 13 in $10 \mu \mathrm{m}$.

Type :- Lake Baikal, south basin, near the settlement Mangutaj, stones and silt, st. 41, $20 \mathrm{~m}$ depth, 22 June 1998, collector V. Votyakov (holotype: slide 0139-BK collection "Darwin initiative" housed at the Limnological Institute SB RAS, Irkutsk, Russia; isotype: slide 0138-BK, ibid.).

Hippodonta vadosa Pomazkina \& Sherbakova sp. nov. (Pomazkina et al., 2018, p. 36, Table 29)

Valve rhombic-lanceolate with narrow protracted cuneal ends. Valve length $17.8 \mu \mathrm{m}$, width $4.7 \mu \mathrm{m}$. Axial area narrow, linear, the central area transapically widening forming incomplete fascia with two shortened striae. Raphe filiform, straight with small widening of proximal and distal raphe endings. Striae nearly radiate, spaced in the middle of the valve becoming 
slightly convergent at apices, 14 in $10 \mu \mathrm{m}$.

Type :- Lake Baikal, Anga bay, silt and sand, st. 6, $17 \mathrm{~m}$ depth, 27 June 1997, collector V. Votyakov (holotype: slide 0114-BK collection "Darwin initiative" housed at the Limnological Institute SB RAS, Irkutsk, Russia; isotype: slide 0115-BK, ibid.).

Hippodonta ventricosa Pomazkina \& Sherbakova sp. nov. (Pomazkina et al., 2018, p. 37, Table 30)

Valves elliptically-lanceolate with broadlyrounded weakly protracted ends. Valve length 13.0$19.0 \mu \mathrm{m}$, width 4.0-4.5 $\mu \mathrm{m}$. Axial area narrow, linear, the central area small, rounded. Raphe filiform, straight with wide teardrop-shaped proximal and distal raphe endings deflected into the same side. Striae nearly radiate in the middle of the valve becoming parallel and slightly convergent at apices, 15-16 in $10 \mu \mathrm{m}$.

Type :- Lake Baikal, southern basin, near the settlement B. Koty, epilithon, st. 1, $20 \mathrm{~m}$ depth, 22 June 1997, collector V. Votyakov (holotype: slide 0001-BK collection "Darwin initiative" housed at the Limnological Institute SB RAS, Irkutsk, Russia; isotype: slide 0001a-BK, ibid.).

\section{Genus Irkutia Pomazkina, Rodionova \& Sherba- kova gen. nov.}

Type generic: Irkutia dispersepunctata (Skabitchevsky) Pomazkina \& Rodionova comb. nov. (Pomazkina et al., 2018, p. 37)

Cells biraphid, valves isopolar, "naviculoid". Characters of the chloroplast is not yet known. Valves linear to linear-elliptic. Ends slightly protracted, cuneate and obtusely rounded. Raphe filiform, weakly lateral, with fine central endings and long widely rounded to the same side terminal fissures. Striae slightly radiate, punctate.

Central raphe endings slit-like with small pores slightly deflected to the primary side (with an exception of Irkutia baicalensis Pomazkina, Rodionova \& Sherbakova with short proximal endings abruptly bent contrary). Terminal raphe fissures hooked, both bent in the direction opposite to proximal endings. Striae punctate, slightly radiate, composed of irregular large transapically widened oval areolae. Axial area broad, linear; central area slightly asymmetrically expanded. Axial and central areas are encircled by a row or rows of larger rounded or oval areolae. Internal proximal raphe endings slit-like, short, bent in the same side; distally, the raphe ends with helictoglossae.

Irkutia baicalensis Pomazkina, Rodionova \& Sherbakova sp. nov. (Pomazkina et al., 2018, p. 39, Table 31)

Valves linear-elliptic with parallel margins. Length 22-43 $\mu \mathrm{m}$, width 5.3-6.7 $\mu \mathrm{m}$. Raphe slightly lateral, filiform with fine central endings that deflected oppositely, terminal fissures widely rounded in the same side. Axial area broad, linear; central area slightly expanded and asymmetric. Striae coarsely punctuate, radiate, 15-16 in $10 \mu \mathrm{m}$. Areolae in striae irregular.

Type :- Lake Baikal, the Cape Rytyi, epilithon, st. 10, 20 m depth, 28 June 1997, collector V. Votyakov (holotype: slide 0033-BK collection "Darwin initiative" housed at the Limnological Institute SB RAS, Irkutsk, Russia; isotype: slide 0034-BK, ibid.).

Irkutia dispersepunctata (Skabitchevsky) Pomazkina \& Rodionova comb. nov. (Pomazkina et al., 2018, p. 39, Table 32)

Basionym: Navicula dispersepunctata Skabitchevsky 1936, p. 712, pl. 2, fig. 16.

Valves broadly linear with parallel margins. Ends cuneate, slightly protracted. Length 54-60 $\mu \mathrm{m}$, width 13.5-14.0 $\mu \mathrm{m}$. Raphe slightly lateral, filiform with small central pores, terminal fissures long widely rounded oppositely. Axial area broad, linear; central area slightly expanded. Striae coarse, unevenly punctuate, parallel, 13-15 in $10 \mu \mathrm{m}$, becoming radiate towards apices, 15-17 in $10 \mu \mathrm{m}$.

Irkutia memorabilis Rodionova \& Pomazkina sp. nov. (Pomazkina et al., 2018, p. 39, Table 33)

Valves linear-elliptic with parallel margins. Ends cuneate obtusely rounded. Length 36-40 $\mu \mathrm{m}$, width 9.2-9.8 $\mu \mathrm{m}$. Raphe slightly lateral, filiform with fine central endings, terminal fissures bent to the same side. Axial area broad, linear; central area slightly expanded. Striae coarse, unevenly punctate, parallel, 13-15 in 10 $\mu \mathrm{m}$, becoming radiate towards apices, 15-17 in $10 \mu \mathrm{m}$.

Type :-Russia, Lake Baikal, the Cape Rytyi, epilithon, st. 10, 20 m depth, 28 June 1997, collector V. Votyakov (holotype: slide 0032-BK collection "Darwin initiative" housed at the Limnological Institute SB RAS, Irkutsk, Russia; isotype: slide 0033-BK, ibid.).

\section{Genus Navicula Bory}

Navicula admiranda Pomazkina, Rodionova \& Sherbakova sp. nov. (Pomazkina et al., 2018, p. 41, Table 34)

Valves lanceolate with strongly protracted rostrate ends. Length 50-67 $\mu \mathrm{m}$, width 5.3-6.7 $\mu \mathrm{m}$. Raphe filiform, straight. Axial area narrow; linear; central area transapically widened. Striae lineolate, radiate in the middle of the valve, $8-10$ in $10 \mu \mathrm{m}$, convergent at the apices, $10-12$ in $10 \mu \mathrm{m}$. Areolae comparatively dense.

Type :-Russia, Lake Baikal, the Olkhon Gates Strait, the Cape Khara-khulun, epilithon, st. 51, $20 \mathrm{~m}$ depth, 25 June 1998, collector V. Votyakov (holotype: slide 0177-BK collection "Darwin initiative" housed at the Limnological Institute SB RAS, Irkutsk, Russia; isotype: slides 0173-BK, 0176- BK, ibid).

Navicula affinibaicalensis Pomazkina, Rodionova \& Sherbakova sp. nov. (Pomazkina et al., 2018, p. 42, Table 36)

Valves linear-lanceolate with protracted rounded ends. Length 118-140 $\mu \mathrm{m}$, width 16-20 $\mu \mathrm{m}$. Raphe filiform, straight, slightly lateral. Axial area narrow becoming wider towards the center; central area indistinct. Striae lineolate, radiate in the middle of the valve, convergent at the apices, 10-12 in $10 \mu \mathrm{m}$. Proximal raphe endings with pores, terminal fissures thin, bent.

Type :-Russia. Lake Baikal, Olkhon Island, the Cape Ukhan, epilithon and algae, st. 8, $15 \mathrm{~m}$ depth, 
28 June 1997, collector V. Votyakov (holotype: slide 0022-BK collection "Darwin initiative" housed at the Limnological Institute SB RAS, Irkutsk, Russia; isotype: slide 0023-BK, ibid.).

Navicula angensis Rodionova \& Pomazkina sp. nov. (Pomazkina et al., 2018, p. 43, Table 38)

Valves lanceolate with strongly protracted sharply rounded ends. Length 43-66 $\mu \mathrm{m}$, width 11-13 $\mu \mathrm{m}$. Raphe Straight, slightly lateral. Axial area moderately broad, lanceolate; central area small, oval. Striae lineolate, uneven in length, radiate in the middle of the valve, 8-10 in $10 \mu \mathrm{m}$, parallel or convergent at the apices, $12-13$ in $10 \mu \mathrm{m}$. Proximal raphe endings with pores, terminal fissures widened, then fine and rounded.

Type :-Russia, Lake Baikal, Anga Bay, silt and sand, st. 6, $17 \mathrm{~m}$ depth, 27 June 1997, collector V. Votyakov (holotype: slide 0014-BK collection "Darwin initiative" housed at the Limnological Institute SB RAS, Irkutsk, Russia; isotype: slides 0015-BK, 0016-BK, ibid.).

Navicula baicaloblonga Pomazkina, Rodionova \& Sherbakova sp. nov. (Pomazkina et al., 2018, p. 44, Table 41)

Valves linear-lanceolate with broadly rounded ends. Length 85-115 $\mu \mathrm{m}$, width 13.8-17.5 $\mu \mathrm{m}$. Raphe filiform, slightly lateral. Axial area narrow; linear; central area rounded. Striae lineolate, radiate, in the middle of the valve, 7-8 in $10 \mu \mathrm{m}$, at the apices, 9-10 in $10 \mu \mathrm{m}$. Proximal raphe endings with pores, terminal fissures widened, then fine and bent to one side.

Type :-Russia, Lake Baikal, near Baikalsk sity, silt, st. 40, $20 \mathrm{~m}$ depth, 23 June 1998, collector V. Votyakov (holotype: slide 0145-BK collection "Darwin initiative" housed at the Limnological Institute SB RAS, Irkutsk, Russia; isotype: slide 0146-BK, ibid.).

Navicula baicalocylindrata Rodionova \& Pomazkina sp. nov. (Pomazkina et al., 2018, p. 45, Table 43)

Valves linear-elliptic with broadly rounded slightly protracted ends. Length 15-19 $\mu \mathrm{m}$, width 4.0-4.2 $\mu \mathrm{m}$. Raphe filiform, curved. Axial area narrow; linear; central rhombic, widened transapically. Striae lineolate, strongly radiate in the middle of the valve, then abruptly parallel, 16-18 in $10 \mu \mathrm{m}$. Proximal raphe endings thing, terminal fissures hooked, bent to one side.

Type :-Russia, Lake Baikal, near Baikalsk sity, silt, st. 47, $20 \mathrm{~m}$ depth, 23 June 1998, collector V. Votyakov (holotype: slide 0165-BK collection "Darwin initiative" housed at the Limnological Institute SB RAS, Irkutsk, Russia; isotype: slide 0166-BK, ibid.).

Navicula baicalogregaria Pomazkina, Rodionova \& Sherbakova sp. nov. (Pomazkina et al., 2018, p. 45, Table 44)

Valves linear-lanceolate with protracted cuneate ends. Length 21-22 $\mu \mathrm{m}$, width 3.7-3.8 $\mu \mathrm{m}$. Raphe filiform, uneven. Axial area narrow; linear; central area transapically oval. Striae lineolate, strongly radiate in the middle of the valve, then parallel, 10-11 in $10 \mu \mathrm{m}$. Proximal raphe endings thing, terminal fissures hooked, bent to the secondary side.
Type :-Russia, Lake Baikal, the Olkhon Gates Strait, cape Khara-khulun, epilithon, st. 51, 20 m depth, 25 June 1998, collector V. Votyakov (holotype: slide 0177-BK collection "Darwin initiative" housed at the Limnological Institute SB RAS, Irkutsk, Russia; isotype: slide $0176-\mathrm{BK}$, ibid.).

Navicula caudata var. austrolacustris Rodionova \& Pomazkina var. nov. (Pomazkina et al., 2018, p. 45, Table 48)

Valves linear-elliptic with protracted cuneate ends. Length 45-46 $\mu \mathrm{m}$, width 15.0-16.0 $\mu \mathrm{m}$. Raphe weakly lateral, straight. Axial area moderate; central area small, rounded. Striae lineolate, radiate, 7-8 in $10 \mu \mathrm{m}$, weakly convergent at apices, 9-10 in $10 \mu \mathrm{m}$. Proximal raphe endings with pores, terminal fissures widened, then fine, rounded. Hyaline uneven bands parallel to the edge of the valve.

Type :-Russia, Lake Baikal, near Baikalsk city, silt, st. 40, $20 \mathrm{~m}$ depth, 23 June 1998, collector V. Votyakov (holotype: slide 0145-BK collection "Darwin initiative" housed at the Limnological Institute SB RAS, Irkutsk, Russia; isotype: slide 0146-BK, ibid.).

Navicula caudata var. elliptica Pomazkina, Rodionova \& Sherbakova var. nov. (Pomazkina et al., 2018, p. 47, Table 49)

Valves elliptic with cuneate ends. Length 47-54 $\mu \mathrm{m}$, width 17.0-21.0 $\mu \mathrm{m}$. Raphe weakly lateral, straight. Axial area broad; central area transapically oval. Striae lineolate, radiate, 8-9 in $10 \mu \mathrm{m}$, becoming parallel at the apices, 9-10 in $10 \mu \mathrm{m}$. In the middle of the valve long striae alternate short. Proximal raphe endings with pores, terminal fissures widened, then thin and rounded. Hyaline uneven discontinuous bands parallel to the edge of the valve.

Type :-Russia, Lake Baikal, island Olkhon, the Khoboj cape, epilithon and algae, st. 9, $20 \mathrm{~m}$ depth, 28 June 1997, collector V. Votyakov (holotype: slide 0027-BK collection "Darwin initiative" housed at the Limnological Institute SB RAS, Irkutsk, Russia; isotype: slide 0028-BK, ibid.).

Navicula caudata var. romboidea Pomazkina, Rodionova \& Sherbakova var. nov. (Pomazkina et al., 2018, p. 48, Table 50)

Valves elliptically-rhombic with cuneate ends. Length 47-50 $\mu \mathrm{m}$, width 19.0-20.0 $\mu \mathrm{m}$. Raphe weakly lateral, straight. Axial area narrow; central area transapically widened. Striae lineolate, radiate, 8-9 in $10 \mu \mathrm{m}$, becoming parallel or slightly convergent at the apices, 9-10 in $10 \mu \mathrm{m}$. In the middle of the valve striae shortened. Proximal raphe endings with pores, terminal fissures widened, then thin and rounded. Hyaline patches irregular on the valve.

Type :-Russia, Lake Baikal, the Olkhon Gates Strait, Antikhai bay, epilithon, st. 50, $5 \mathrm{~m}$ depth, 25 June 1998, collector V. Votyakov (holotype: slide 0173-BK collection "Darwin initiative" housed at the Limnological Institute SB RAS, Irkutsk, Russia; isotype: slide 0174-BK, ibid.).

Navicula caudata var. skvortzowii Rodionova \& Pomazkina var. nov. (Pomazkina et al., 2018, p. 48, Table 51)

Valve elliptic with cuneate slightly protracted 
ends. Length 41.8-50 $\mu \mathrm{m}$, width $17.3 \mu \mathrm{m}$. Raphe weakly lateral, straight. Axial area moderately broad; central area rounded, transapically widened. Striae lineolate, radiate, becoming parallel at the apices, 9-10 in $10 \mu \mathrm{m}$. In the middle of the valve long striae alternate short. Distinct striae interrupted with hyaline patches. Proximal raphe endings with pores, terminal fissures rounded.

Type :-Russia, Lake Baikal, south basin, near the settlement Mangutaj, stones and silt, st. 41, $20 \mathrm{~m}$ depth, 22 June 1998, collector V. Votyakov (holotype: slide 0138-BK collection "Darwin initiative" housed at the Limnological Institute SB RAS, Irkutsk, Russia; isotype: slide 0140-BK, ibid.).

Navicula cryptocephala var. baicalensis Rodionova \& Pomazkina var. nov. (Pomazkina et al., 2018, p. 49, Table 53)

Valves lanceolate with slightly protracted capitates ends. Length 20.1-25.6 $\mu$ m, width 4.5-5.6 $\mu \mathrm{m}$. Raphe filiform, weakly uneven, lateral. Axial area narrow; central area small, rhombic-rounded, asymmetric. Striae lineolate, slightly radiate, convergent at the apices, 18-20 in $10 \mu \mathrm{m}$. Proximal raphe endings straight with pores, terminal fissures long, bent to one side.

Type :-Russia, Lake Baikal, south basin, near the settlement Mangutaj, stones and silt, st. 41, $20 \mathrm{~m}$ depth, 22 June 1998, collector V. Votyakov (holotype: slide 0138-BK collection "Darwin initiative" housed at the Limnological Institute SB RAS, Irkutsk, Russia; isotype: slide 0139-BK, ibid.).

Navicula hasta var. austrolacustris Rodionova \& Pomazkina var. nov. (Pomazkina et al., 2018, p. 51, Table 57)

Valves lanceolate with protracted rostrate ends. Length 53-54 $\mu \mathrm{m}$, width 11.0-11.7 $\mu \mathrm{m}$. Raphe filiform, weakly lateral. Axial area narrow, lineal; central area transapically widened. Striae lineolate, radiate, in the center 8-9 in $10 \mu \mathrm{m}$, at the apices $11-12$ in $10 \mu \mathrm{m}$. Proximal raphe endings with pores, terminal fissures long, bent to one side.

Type :-Russia, Lake Baikal, south basin, near the settlement Mangutaj, stones and silt, st. 41, $20 \mathrm{~m}$ depth, 22 June 1998, collector V. Votyakov (holotype: slide 0138-BK collection "Darwin initiative" housed at the Limnological Institute SB RAS, Irkutsk, Russia; isotype: slides 0139-BK, 0140-BK, 0141-BK, ibid.).

Navicula hasta var. baicalensis Rodionova \& Pomazkina var. nov. (Pomazkina et al., 2018, p. 51, Table 58)

Valves lanceolate with sharply rounded ends. Length 93-104 $\mu \mathrm{m}$, width 16.0-17.1 $\mu \mathrm{m}$. Raphe filiform, weakly lateral. Axial area moderate, lineal; central area small rounded. Striae lineolate, radiate, in the center 5-6 in $10 \mu \mathrm{m}$, at the apices 9-10 in $10 \mu \mathrm{m}$. Proximal raphe endings with pores, terminal fissures long, bent to one side.

Type :-Russia, Lake Baikal, near the settlement south basin, stones and silt, st. 41, $20 \mathrm{~m}$ depth, 22 June 1998, collector V. Votyakov (holotype: slide 0138-BK collection "Darwin initiative" housed at the Limnological Institute SB RAS, Irkutsk, Russia; isotype: slides 0139-BK, 0140-BK, 0141-BK, ibid.).

Navicula lacusbaicali var. ottochuschinica Pomazkina, Rodionova \& Sherbakova var. nov. (Pomazkina et al., 2018, p. 53, Table 63)

Valves elliptically-lanceolate with cuneate ends. Length 23-37 $\mu \mathrm{m}$, width 9.7-13.5 $\mu \mathrm{m}$. Raphe weakly lateral, straight. Axial area broad; central area small, transapically widened, asymmetric. Striae lineolate, weakly radiate, 9-10 in $10 \mu \mathrm{m}$, becoming parallel or slightly convergent at the apices, $10-12$ in $10 \mu \mathrm{m}$. In the middle of the valve striae shortened. Distinct hyaline patches on one half of the valve. Proximal raphe endings with pores, terminal fissures long, fine.

Type :-Russia, Lake Baikal, the Olkhon Gates Strait, the Cape Otto-Khushin, epilithon, st. 53, $20 \mathrm{~m}$ depth, 25 June 1998, collector V. Votyakov (holotype: slide 0183-BK collection "Darwin initiative" housed at the Limnological Institute SB RAS, Irkutsk, Russia; isotype: slide 0184-BK, ibid).

Navicula latilanceolata Rodionova \& Pomazkina sp. nov. (Pomazkina et al., 2018, p. 54, Table 64)

Valves broadly lanceolate with weakly protracted narrowly rounded ends. Length $22-23 \mu \mathrm{m}$, width 7.6-8.0 $\mu \mathrm{m}$. Raphe filiform. Axial area narrow, linear; central area small, rounded. Striae lineolate, radiate, becoming slightly convergent at the apices, 14 in $10 \mu \mathrm{m}$. Proximal raphe endings with pores, terminal fissures short hooked.

Type :-Russia, Lake Baikal, Anga Bay, silt and sand, st. 6, $17 \mathrm{~m}$ depth, 27 June 1997, collector V. Votyakov (holotype: slide 0014-BK collection "Darwin initiative" housed at the Limnological Institute SB RAS, Irkutsk, Russia; isotype: slides 0015-BK, 0016-BK, ibid.).

Navicula menisculus var. baicalensis Rodionova \& Pomazkina var. nov. (Pomazkina et al., 2018, p. 56, Table 69)

Valves elliptical-lanceolate with weakly protracted narrowly rounded ends. Length 18.7-26.2 $\mu \mathrm{m}$, width 8.4-10.5 $\mu \mathrm{m}$. Raphe filiform. Axial area narrow, linear; central area small, rounded. Striae lineolate, slightly radiate in the center, becoming almost parallel at the apices, 12-14 in $10 \mu \mathrm{m}$. Proximal raphe endings with pores, terminal fissures short hooked.

Type :-Russia, Lake Baikal, northern basin, the Cape Elokhin, sand, st. 12.3, $4 \mathrm{~m}$ depth, 29 June 1997, collector V. Votyakov (holotype: slide 0043-BK collection "Darwin initiative" housed at the Limnological Institute SB RAS, Irkutsk, Russia; isotype: slide 0043b-BK, ibid.).

Navicula meridielacum Rodionova \& Pomazkina sp. nov. (Pomazkina et al., 2018, p. 56, Table 70)

Valves lanceolate with obtusely rounded elongated ends. Length 68-79 $\mu \mathrm{m}$, width 14.4-15.8 $\mu \mathrm{m}$. Raphe slightly lateral. Axial area narrow, linear; central area transapically widened. Striae lineolate, radiate, in the center 8-9 in $10 \mu \mathrm{m}$, denser at the apices, 10-11 in $10 \mu \mathrm{m}$. Proximal raphe endings with pores, terminal fissures widened then fine and rounded.

Type :-Russia, Lake Baikal, near the city of Baikalsk, silt, st. 40, 20 m depth, 23 June 1998, collector V. Votyakov (holotype: slide 0145-BK collection "Darwin initiative" housed at the Limnological Institute 
SB RAS, Irkutsk, Russia; isotype: slide 0145a-BK, ibid.). Navicula meridielacum var. skvortzowii Pomazkina, Rodionova \& Sherbakova var. nov. (Pomazkina et al., 2018, p. 57, Table 71)

Valves lanceolate with weakly protracted rounded ends. Length 91-108 $\mu \mathrm{m}$, width 17.4-19.2 $\mu \mathrm{m}$. Raphe slightly lateral. Axial area moderate; central area transapically widened, asymmetric. Striae lineolate, radiate, in the middle of the valve long striae alternate short, 6-8 in $10 \mu \mathrm{m}$. Striae slightly denser at the apices, 9-10 in $10 \mu \mathrm{m}$. Proximal raphe endings with marked pores, terminal fissures widened then fine and rounded.

Type :-Russia, Lake Baikal, south basin, near the settlement Mangutaj, stones and silt, st. 41, $20 \mathrm{~m}$ depth, 22 June 1998, collector V. Votyakov (holotype: slide 0138-BK collection "Darwin initiative" housed at the Limnological Institute SB RAS, Irkutsk, Russia; isotype: slide 0139-BK, ibid.).

Navicula neooppugnata Rodionova \& Pomazkina sp. nov. (Pomazkina et al., 2018, p. 58, Table 73)

Valves lanceolate with weakly protracted cuneate ends. Length 37-60 $\mu \mathrm{m}$, width 7.8-11.6 $\mu \mathrm{m}$. Raphe slightly lateral. Axial area narrow, linear; central area transapically elliptic. Striae lineolate, radiate in the middle of the valve, 8-10 in $10 \mu \mathrm{m}$, becoming almost convergent towards the apices, $10-12$ in $10 \mu \mathrm{m}$. Proximal raphe endings with pores, terminal fissures widened then fine and rounded.

Type :-Russia, Lake Baikal, near the city of Baikalsk, silt, st. 40, 20 m depth, 23 June 1998, collector V. Votyakov (holotype: slide 0145-BK collection "Darwin initiative" housed at the Limnological Institute SB RAS, Irkutsk, Russia; isotype: slide 0145b-BK, ibid.).

Navicula picea var. paucimarensis Rodionova \& Pomazkina var. nov. (Pomazkina et al., 2018, p. 60, Table 79)

Valves lanceolate with weakly protracted sharply rounded ends. Length 31-32 $\mu \mathrm{m}$, width 6.1-6.3 $\mu \mathrm{m}$. Raphe slightly lateral. Axial area narrow; central area lanceolate, small. Striae lineolate, radiate, becoming convergent towards the apices, $16-18$ in $10 \mu \mathrm{m}$. Proximal raphe endings with pores, terminal fissures broadly rounded.

Type :-Russia, Lake Baikal, the Olkhon Gates Strait, the Cape Khara-Khulun, epilithon, st. 51, $20 \mathrm{~m}$ depth, 25 June 1998, collector V. Votyakov (holotype: slide 0176-BK collection "Darwin initiative" housed at the Limnological Institute SB RAS, Irkutsk, Russia; isotype: slide 0177-BK, ibid).

Navicula pseudoajajensis Pomazkina, Rodionova \& Sherbakova sp. nov. (Pomazkina et al., 2018, p. 61, Table 81)

Valves lanceolate with obtusely rounded ends. Length 56-58 $\mu \mathrm{m}$, width 13-15 $\mu \mathrm{m}$. Raphe slightly lateral. Axial area wide, linear; central area small, rounded. Striae lineolate, in the middle of the valve long striae alternate short, radiate, becoming parallel then slightly convergent at the apices, $11-12$ in 10 $\mu \mathrm{m}$. Proximal raphe endings with wide pores, terminal fissures widened, then thin and rounded.

Type :-Russia, Lake Baikal, the Olkhon Gates Strait, M. Mujgin bay, epilithon, st. 52, $20 \mathrm{~m}$ depth,
25 June 1998, collector V. Votyakov (holotype: slide 0179-BK collection "Darwin initiative" housed at the Limnological Institute SB RAS, Irkutsk, Russia; isotype: slide 0179a-BK, ibid).

Navicula pseudobaicalensis Pomazkina, Rodionova \& Sherbakova sp. nov. (Pomazkina et al., 2018, p. 62, Table 82)

Valves lanceolate with long narrowly-rounded ends. Length 67-72 $\mu \mathrm{m}$, width 9.3-10.4 $\mu \mathrm{m}$. Raphe filiform. Axial area narrow; central area small, oval or rounded. Striae lineolate, radiate in the middle of the valve, 9-10 in $10 \mu \mathrm{m}$, becoming convergent at the apices, 16-18 in $10 \mu \mathrm{m}$. Proximal raphe endings hooked, terminal fissures long bent to the primary valve side.

Type :-Russia. Lake Baikal, the Olkhon Gates Strait, epilithon, st. 7, 20 m depth, 27 June 1997, collectorV.Votyakov (holotype: slide 0017-BK collection "Darwin initiative" housed at the Limnological Institute SB RAS, Irkutsk, Russia; isotype: slides 0018-BK, 0019BK, ibid.).

Navicula pseudosemenicula Rodionova \& Pomazkina sp. nov. (Pomazkina et al., 2018, p. 62, Table 84)

Valves lanceolate with slightly protracted obtusely-rounded ends. Length 67-72 $\mu \mathrm{m}$, width 9.3-10.4 $\mu \mathrm{m}$. Raphe filiform. Axial area narrow; central area small, oval or rouneded. Striae lineolate, in the middle of the valve radiate, 9-10 in $10 \mu \mathrm{m}$, becoming convergent at the apices, $16-18$ in $10 \mu \mathrm{m}$. Proximal raphe endings hooked, terminal fissures long bent to the primary valve side.

Type :-Russia. Lake Baikal, the Olkhon Gates Strait, epilithon, st. 7, 20 m depth, 27 June 1997, collectorV. Votyakov (holotype: slide 0017-BK collection "Darwin initiative" housed at the Limnological Institute SB RAS, Irkutsk, Russia; isotype: slides 0018-BK, 0019BK, 0020-BK, 0021-BK, ibid.).

Navicula quasibaicalensis Pomazkina, Rodionova \& Sherbakova sp. nov. (Pomazkina et al., 2018, p. 63, Table 85)

Valves narrowly-lanceolate with long protracted narrowly-rounded ends. Length 101-115 $\mu \mathrm{m}$, width 14.3-19.0 $\mu \mathrm{m}$. Raphe slightly lateral. Axial area narrow; central area small, rounded. Striae lineolate, radiate, in the middle of the valve, 7-10 in $10 \mu \mathrm{m}$, at the apices, 11-13 in $10 \mu \mathrm{m}$. Proximal raphe endings with pores, terminal fissures hooked, bent to the primary valve side.

Type :-Russia, Lake Baikal, southern basin, near the settlement Kultuk, epilithon, st. 42, $20 \mathrm{~m}$ depth, 22 June 1998, collector V. Votyakov (holotype: slide 0132-BK collection "Darwin initiative" housed at the Limnological Institute SB RAS, Irkutsk, Russia; isotype: slide 0132a-BK, ibid.).

Navicula quasibaicalensis var. inflata Rodionova \& Pomazkina var. nov. (Pomazkina et al., 2018, p. 64, Table 86)

Valves broadly-lanceolate with long protracted narrowly-rounded ends. Length 105-114 $\mu \mathrm{m}$, width 20.4-21.0 $\mu \mathrm{m}$. Raphe slightly lateral. Axial area narrow; central area small, rounded. Striae lineolate, 
radiate, in the middle of the valve, $7-8$ in $10 \mu \mathrm{m}$, at the apices, $10-11$ in $10 \mu \mathrm{m}$. Proximal raphe endings with pores, terminal fissures hooked, bent to the primary valve side.

Type :-Russia, Lake Baikal, south basin, near the settlement Mangutaj, stones and silt, st. 41, $20 \mathrm{~m}$ depth, 22 June 1998, collector V. Votyakov (holotype: slide 0138-BK collection "Darwin initiative" housed at the Limnological Institute SB RAS, Irkutsk, Russia; isotype: slide 0139-BK, slides 0140-BK, slide 0141-BK, ibid.).

Navicula quasibaicalensis var. paucimarensis Pomazkina, Rodionova \& Sherbakova var. nov. (Pomazkina et al., 2018, p. 64, Table 87)

Valves lanceolate with long protracted narrowlyrounded ends. Length 53-68 $\mu \mathrm{m}$, width 10.0-11.9 $\mu \mathrm{m}$. Raphe filiform. Axial area narrow; central area large, rounded. Striae lineolate, radiate in the middle of the valve, 8-9 in $10 \mu \mathrm{m}$, becoming almost parallel at the apices, $10-13$ in $10 \mu \mathrm{m}$. Proximal raphe endings with pores, terminal fissures widened, then thin and rounded to the same side.

Type :-Russia, Lake Baikal, the Olkhon Gates Strait, the Cape Khara-Khulun, epilithon, st. 51, $20 \mathrm{~m}$ depth, 25 June 1998, collector V. Votyakov (holotype: slide 0177-BK, collection "Darwin initiative" housed at the Limnological Institute SB RAS, Irkutsk, Russia; isotype: slides 0176-BK, 0173-BK ibid).

Navicula reinchardtiana var. baicalensis Rodionova \& Pomazkina var. nov. (Pomazkina et al., 2018, p. 66, Table 91)

Valves broadly-lanceolate with protracted obtusely-rounded ends. Length 24-27 $\mu \mathrm{m}$, width 7.5-8.5 $\mu \mathrm{m}$. Raphe filiform. Axial area narrow; central area almost round, asymmetric. Striae lineolate, radiate, shortened in the middle of the valve becoming slightly convergent or parallel towards the apices, 13-16 in $10 \mu \mathrm{m}$. Proximal raphe endings with pores, terminal fissures weakly widened and slightly bent.

Type :-Russia, Lake Baikal, the Olkhon Gates Strait, the Cape Khara-Khulun, epilithon, st. 51, $20 \mathrm{~m}$ depth, 25 June 1998, collector V. Votyakov (holotype: slide 0176-BK, collection "Darwin initiative" housed at the Limnological Institute SB RAS, Irkutsk, Russia; isotype: slides 0177-BK, 0178-BK, ibid).

Navicula rhombicinsolitum Pomazkina, Rodionova \& Sherbakova sp. nov. (Pomazkina et al., 2018, p.67, Table 95)

Valves elliptic-lanceolate or rhombic-lanceolate with protracted sharply-rounded ends. Length 69-77 $\mu \mathrm{m}$, width 16.7-19.4 $\mu \mathrm{m}$. Raphe slightly lateral, straight. Axial area wide; central area rounded. Striae lineolate, weakly radiate in the middle of the valve, $7-8$ in $10 \mu \mathrm{m}$, becoming parallel, then convergent towards the apices, 9-10 in $10 \mu \mathrm{m}$. Hyaline uneven areas one each half of the valve. Proximal raphe endings with pores, terminal ends short, widened, bent to the secondary valve side.

Type :-Russia, Lake Baikal, the Olkhon Gates Strait, the Cape Khara-Khulun, epilithon, st. 51, $20 \mathrm{~m}$ depth, 25 June 1998, collector V. Votyakov (holotype: slide 0176-BK, collection "Darwin initiative" housed at the Limnological Institute SB RAS, Irkutsk, Russia; isotype: slides 0177-BK, 0178-BK, ibid).

Navicula subajajensis var. skvortzowii Rodionova \& Pomazkina var. nov. (Pomazkina et al., 2018, p. 69, Table 98)

Valves linear-lanceolate with cuneate slightly protracted ends. Length 60-68 $\mu \mathrm{m}$, width 12.8-13.0 $\mu \mathrm{m}$. Raphe slightly lateral, curved proximally. Axial area wide, linear; central area small, transapically widened. Striae lineolate, radiate, in the middle of the valve long striae alternate short. Striae becoming parallel or slightly convergent towards the apices, 10-12 in $10 \mu \mathrm{m}$. Proximal raphe endings short forked, terminal endings short hooked.

Type :-Russia, Lake Baikal, the Olkhon Gates Strait, the Cape Otto-Khushin, epilithon, st. 53, $20 \mathrm{~m}$ depth, 25 June 1998, collector V. Votyakov (holotype: slide 0183-BK collection "Darwin initiative" housed at the Limnological Institute SB RAS, Irkutsk, Russia; isotype: slide 0184-BK, ibid).

Navicula subelongata var. meyeri Pomazkina, Rodionova \& Sherbakova var. nov. (Pomazkina et al., 2018, p. 70, Table 100)

Valves linear-lanceolate with cuneate slightly protracted rounded ends. Length 73-76.9 $\mu \mathrm{m}$, width 11.7-13.2 $\mu \mathrm{m}$. Raphe slightly lateral. Axial area wide, lanceolate; central area indistinct. Striae lineolate, radiate, 8-9 in $10 \mu \mathrm{m}$, in the middle of the valve long striae alternate short. Proximal raphe endings with wide pores, terminal fissures long, bent.

Type :-Russia, Lake Baikal, south basin, near the settlement Mangutaj, stones and silt, st. 41, $20 \mathrm{~m}$ depth, 22 June 1998, collector V. Votyakov (holotype: slide 0138-BK collection "Darwin initiative" housed at the Limnological Institute SB RAS, Irkutsk, Russia; isotype: slide 0140-BK, ibid.).

Navicula vadosa Pomazkina, Rodionova \& Sherbakova sp. nov. (Pomazkina et al., 2018, p. 71, Table 104)

Valve broad lanceolate with protracted rostrate ends. Length $39 \mu \mathrm{m}$, width $11.7 \mu \mathrm{m}$. Raphe filiform. Axial area narrow; central area small, oval. Striae lineolate, radiate in the middle of the valve becoming slightly convergent towards the apices, 10-11 in 10 $\mu \mathrm{m}$. Proximal raphe endings with large pores, terminal fissures long, bent to the same side.

Type :-Russia, Lake Baikal, the central basin, the River Selenga delta, silt, st. 32, $15 \mathrm{~m}$ depth, 06 July 1997, collector V. Votyakov (holotype: slide 0109-BK collection "Darwin initiative" housed at the Limnological Institute SB RAS, Irkutsk, Russia; isotype: slide 0109a-BK, ibid.).

Navicula vasilii Rodionova sp. nov. (Pomazkina et al., 2018, p. 71, Table 105)

Valve lanceolate with slightly protracted rounded ends. Length $16.6 \mu \mathrm{m}$, width $5.1 \mu \mathrm{m}$. Raphe filiform. Axial area narrow; central area small, transapically widened. Striae irregular: uniseriate, occasionally biseriate, lineolate, punctuate, radiate in the middle of the valve, 16 in $10 \mu \mathrm{m}$, becoming parallel at the apices, 18 in $10 \mu \mathrm{m}$. Proximal raphe endings with large pores, terminal fissures long, bent to the secondary side.

Type :-Russia, Lake Baikal, near the city of 
Baikalsk, silt, st. 40, 20 m depth, 23 June 1998, collector V. Votyakov (holotype: slide 0145-BK collection "Darwin initiative" housed at the Limnological Institute SB RAS, Irkutsk, Russia; isotype: slide 0145a-BK, ibid.).

Navicula viridula var. baicalensis Rodionova \& Pomazkina var. nov. (Pomazkina et al., 2018, p. 72, Table 106)

Valves linear-lanceolate with obtuse-rounded ends. Length 56-57 $\mu \mathrm{m}$, width 8.6-9.0 $\mu \mathrm{m}$. Raphe filiform. Axial area narrow, straight; central area rectangular transapically widened. Striae lineolate, strongly radiate, in the middle of the valve, convergent at the apices, 10-11 in $10 \mu \mathrm{m}$. Proximal raphe endings with pores, terminal fissures widened then thin and rounded.

Type :-Russia, Lake Baikal, the River Selenga delta, silt, st. 32, 15 m depth, 06 July 1997, collector V. Votyakov (holotype: slide 0109-BK collection "Darwin initiative" housed at the Limnological Institute SB RAS, Irkutsk, Russia; isotype: slide 0109a-BK, ibid.).

Navicula visenda Pomazkina, Rodionova \& Sherbakova sp. nov. (Pomazkina et al., 2018, p. 73, Table 108)

Valves broad lanceolate with slightly protracted rounded ends. Length 35-45 $\mu \mathrm{m}$, width 9.7-10.9 $\mu \mathrm{m}$. Raphe slightly lateral. Axial area narrow; central area rounded. Striae lineolate, radiate in the middle of the valve, 8-9 in $10 \mu \mathrm{m}$, becoming slightly convergent at the apices, $10-11$ in $10 \mu \mathrm{m}$. Proximal raphe endings with large pores, terminal fissures long, bent to the same side. Proximal raphe endings with pores, terminal fissures broadly bent to the same side.

Type :-Russia, Lake Baikal, the central basin, the River Selenga delta, silt, st. 32, $15 \mathrm{~m}$ depth, 06 July 1997, collector V. Votyakov (holotype: slide 0109-BK collection "Darwin initiative" housed at the Limnological Institute SB RAS, Irkutsk, Russia; isotype: slide 0109c-BK, ibid.).

Navicula vivata Rodionova \& Pomazkina sp. nov. (Pomazkina et al., 2018, p. 73, Table 109)

Valve elliptic-lanceolate with protracted obtusely-rounded ends. Length $26 \mu \mathrm{m}$, width $7 \mu \mathrm{m}$. Raphe slightly lateral and bent. Axial area narrow; central area large, transapically widened. Striae lineolate, strongly radiate in the middle of the valve, becoming slightly convergent towards the apices, 18-20 in $10 \mu \mathrm{m}$. Proximal raphe endings with pores, terminal endings angular, bent to the same valve side.

Type :-Russia, Lake Baikal, the central basin, the River Selenga delta, silt, st. 32, $15 \mathrm{~m}$ depth, 06 July 1997, collector V. Votyakov (holotype: slide 0109-BK collection "Darwin initiative" housed at the Limnological Institute SB RAS, Irkutsk, Russia; isotype: slide 0109c-BK, ibid.).

Navicula witkowskii Pomazkina, Rodionova \& Sherbakova sp. nov. (Pomazkina et al., 2018, p. 74, Table 111)

Valve lanceolate with long narrowly-rounded ends. Length $96.4 \mu \mathrm{m}$, width $16.4 \mu \mathrm{m}$. Raphe filiform. Axial area narrow; central area small, rounded. Striae lineolate, slightly radiate in the middle of the valve, 8 in $10 \mu \mathrm{m}$, becoming strongly radiate at the apices, 10 in $10 \mu \mathrm{m}$. Proximal raphe endings with pores, terminal fissures fine, weakly bent to the same side.

Type :-Russia, Lake Baikal, the northern basin, near the Cape Kabanij, epilithon, st. 22, 20 m depth, 04 July 1997, collector V. Votyakov (holotype: slide 0073-BK collection "Darwin initiative" housed at the Limnological Institute SB RAS, Irkutsk, Russia; isotype: slide 0073a-BK, ibid.).

Navicula xenium Rodionova \& Pomazkina sp. nov. (Pomazkina et al., 2018, p. 75, Table 113)

Valve lanceolate with protracted rounded ends. Length $41 \mu \mathrm{m}$, width $9.4 \mu \mathrm{m}$. Raphe filiform. Axial area narrow; central area small, transapically widened. Striae lineolate, slightly radiate, shortened in the middle of the valve, becoming radiate at the apices, $10-12$ in $10 \mu \mathrm{m}$. Proximal raphe endings with pores, terminal fissures widened, then thin and rounded.

Type :-Russia, Lake Baikal, near the city of Baikalsk, silt, st. 40, 20 m depth, 23 June 1998, collector V. Votyakov (holotype: slide 0145-BK collection "Darwin initiative" housed at the Limnological Institute SB RAS, Irkutsk, Russia; isotype: slide 0145c-BK, ibid.).

\section{Genus Paraplaconeis Kulikovskiy, Lange-Ber- talot \& Metzeltin}

Paraplaconeis ampla Pomazkina \& Rodionova sp. nov. (Pomazkina et al., 2018, p. 78, Table 114)

Valve elliptic-lanceolate with slightly attenuated rostrate ends. Length $81.4 \mu \mathrm{m}$, width $20.7 \mu \mathrm{m}$. Axial area linear, narrow at the apices, widening to the center; central area oval transapically widened. Striae biseriate, radiate, 8-9 in $10 \mu \mathrm{m}$. Raphe filiform, lateral. Proximal raphe endings with pores, terminal thin broadly rounded to the same side.

Type :-Russia, Lake Baikal, the northern basin, near the Cape Kabanij, epilithon, st. 22, $20 \mathrm{~m}$ depth, 04 July 1997, collector V. Votyakov (holotype: slide 0073-BK collection "Darwin initiative" housed at the Limnological Institute SB RAS, Irkutsk, Russia; isotype: slide 0074-BK, ibid.).

Paraplaconeis anfracta Pomazkina sp. nov. (Pomazkina et al., 2018, p. 78, Table 115)

Valves elliptic-lanceolate with slightly attenuated rostrate ends. Length 27.7-31.0 $\mu \mathrm{m}$, width 12.6-15.5 $\mu \mathrm{m}$. Axial area linear, narrow; central area small transapically widened. Striae biseriate, radiate, 10-11 in $10 \mu \mathrm{m}$. Raphe filiform, linear is contoured on either side by wide sinuous depression. Proximal raphe endings with pores, terminal thin broadly rounded to the same side.

Type :-Russia, Lake Baikal, the northern basin, the Cape Orlovij, sand, st. 25, $12 \mathrm{~m}$ depth, 05 July 1997, collector V. Votyakov (holotype: slide 0083-BK collection "Darwin initiative" housed at the Limnological Institute SB RAS, Irkutsk, Russia; isotype: slide 0083a-BK, ibid.).

Paraplaconeis arcuata Pomazkina \& Rodionova sp. nov. (Pomazkina et al., 2018, p. 78, Table 116)

Valve elliptic-lanceolate with slightly attenuated 
rostrate ends. Length 25,6 $\mu \mathrm{m}$, width $12.2 \mu \mathrm{m}$. Axial area linear, narrow; central area small rectangular. Striae biseriate, radiate, 10 in $10 \mu \mathrm{m}$, becoming denser at apices, 20 in $10 \mu \mathrm{m}$. Raphe filiform. Raphe sternum is contoured on either side by wide sinuous depression adjoining to striae. Proximal raphe endings with pores, terminal fissures differently curved to the same side.

Type :-Russia, Lake Baikal, south basin, near the settlement Mangutaj, stones and silt, st. 41, $20 \mathrm{~m}$ depth, 22 June 1998, collector V. Votyakov (holotype: slide 0139-BK collection "Darwin initiative" housed at the Limnological Institute SB RAS, Irkutsk, Russia; isotype: slide 0139a-BK, ibid.).

Paraplaconeis australis Pomazkina \& Rodionova sp. nov. (Pomazkina et al., 2018, p. 79, Table 117)

Valves elliptic-lanceolate with attenuated rostrate ends. Length 38.5-40.8 $\mu \mathrm{m}$, width 12.0-15.7 $\mu \mathrm{m}$. Axial area linear, narrow; central area small slightly transapically widened with shortened central striae. Striae biseriate, radiate, $10-11$ in $10 \mu \mathrm{m}$, becoming strongly radiate and denser at the apices, 13 in $10 \mu \mathrm{m}$. Raphe filiform, proximal endings with pores, terminal fissures rounded to the same side.

Type :-Russia, Lake Baikal, near the city of Baikalsk, silt, st. 40, 20 m depth, 23 June 1998, collector V. Votyakov (holotype: slide 0145-BK collection "Darwin initiative" housed at the Limnological Institute SB RAS, Irkutsk, Russia; isotype: slide 0146-BK, ibid.).

Paraplaconeis baicalensis Pomazkina \& Sherbakova sp. nov. (Pomazkina et al., 2018, p. 79, Table 118)

Valves broad elliptic-lanceolate to rhombic with weakly attenuated rostrate ends. Length $28.4 \mu \mathrm{m}$, width $13.2 \mu \mathrm{m}$. Axial area narrow at the apices widening to the middle of the valve; central area small slightly transapically widened with shortened central striae. Striae biseriate, radiate, $11-12$ in $10 \mu \mathrm{m}$, becoming strongly radiate and closer at the apices, 12-13 in 10 $\mu \mathrm{m}$. Raphe filiform, proximal raphe endings with pores, terminal fissures differently rounded to the same side. Raphe sternum is contoured on either side except for the apices by wide undulated depression adjoining to striae.

Type :-Russia, Lake Baikal, near the city of Baikalsk, silt, st. 40, 20 m depth, 23 June 1998, collector V. Votyakov (holotype: slide 0145-BK collection "Darwin initiative" housed at the Limnological Institute SB RAS, Irkutsk, Russia; isotype: slide 0145a-BK, ibid.).

Paraplaconeis decorata Pomazkina sp. nov. (Pomazkina et al., 2018, p. 80, Table 120)

Valves elliptic-lanceolate with shortly attenuated rostrate ends. Length 30.3-31.0 $\mu \mathrm{m}$, width 13.0-14.0 $\mu \mathrm{m}$. Axial area narrow, linear; central area small transapically elongate oval. Striae radiate, 10 in $10 \mu \mathrm{m}$, becoming closer at the apices, 11-12 in $10 \mu \mathrm{m}$. Raphe filiform, distal endings differently bent to the same side, central raphe pores slightly undulating.

Type :-Russia, Lake Baikal, the northern basin, near the Cape Kabanij, epilithon, st. 22, $20 \mathrm{~m}$ depth, 04 July 1997, collector V. Votyakov (holotype: slide 0073-BK collection "Darwin initiative" housed at the Limnological Institute SB RAS, Irkutsk, Russia; isotype: slide 0074-BK, ibid.).

Paraplaconeis dimidia Pomazkina \& Sherbakova sp. nov. (Pomazkina et al., 2018, p. 81, Table 121)

Valve broad elliptic rhombic-lanceolate with shortly attenuated rostrate ends. Length $46.2 \mu \mathrm{m}$, width 14.6 $\mu \mathrm{m}$. Axial area narrow at the apices widening to the middle of the valve; central area small slightly transapically widened with shortened central striae. Striae radiate, biseriate, $10-11$ in $10 \mu \mathrm{m}$, becoming closer at the apices, 11-12 in $10 \mu \mathrm{m}$. Raphe filiform, distal endings differently bent to the same side, central raphe endings slightly undulating with small pores.

Type :-Russia, Lake Baikal, the southern basin, the Cape Polovinnyj, epilithon, st. 44, 9 m depth, 22 June 1998, collector V. Votyakov (holotype: slide 0126-BK collection "Darwin initiative" housed at the Limnological Institute SB RAS, Irkutsk, Russia; isotype: slide 0125-BK, ibid.).

Paraplaconeis dissimilis Pomazkina \& Rodionova sp. nov. (Pomazkina et al., 2018, p. 81, Table 122)

Valve elliptic-lanceolate with shortly attenuated rostrate ends. Length $52.5 \mu \mathrm{m}$, width $20.0 \mu \mathrm{m}$. Axial area narrow, linear; central area small transapically widened. Striae radiate, becoming biseriate at the apices, 8-9 in $10 \mu \mathrm{m}$. Raphe filiform, linear with proximal pores and weakly undulating distal endings. Raphe sternum is contoured on either side except for the apices by wide undulated depression adjoining to striae.

Type :-Russia, Lake Baikal, the northern basin, near the Cape Kabanij, epilithon, st. 22, $20 \mathrm{~m}$ depth, 04 July 1997, collector V. Votyakov (holotype: slide 0073-BK collection "Darwin initiative" housed at the Limnological Institute SB RAS, Irkutsk, Russia; isotype: slide 0074-BK, ibid.).

Paraplaconeis elongata Pomazkina \& Sherbakova sp. nov. (Pomazkina et al., 2018, p. 82, Table 123)

Valves elliptic-lanceolate with weakly attenuated rostrate ends. Length 62.0-62.8 $\mu \mathrm{m}$, width 19.1-20 $\mu \mathrm{m}$. Axial area narrow, linear; central area almost indistinct. Striae radiate, biseriate, strongly radiate to the apices, 9-10 in $10 \mu \mathrm{m}$. Raphe filiform, proximal endings linear with small pores, distal endings differently curved to the same side. Raphe sternum is contoured on either side by narrow undulated depression adjoining to striae.

Type :-Russia, Lake Baikal, the southern basin, the Cape Polovinnyj, epilithon, st. 44, 9 m depth, 22 June 1998, collector V. Votyakov (holotype: slide 0127-BK collection "Darwin initiative" housed at the Limnological Institute SB RAS, Irkutsk, Russia; isotype: slide 0125-BK, ibid.).

Paraplaconeis foliaris Pomazkina \& Sherbakova sp. nov. (Pomazkina et al., 2018, p. 82, Table 124)

Valves elliptic-lanceolate with rostrate ends. Length 52.7-61.8 $\mu \mathrm{m}$, width 19.1-23.6 $\mu \mathrm{m}$. Axial area narrow at the apices widening to the middle of the valve; central area small weakly transapically widened with shortened central striae. Striae radiate, biseriate, strongly radiate to the apices, 9-10 in $10 \mu \mathrm{m}$. Raphe filiform, proximal endings linear with small pores, distal endings differently curved to the same side. 
Raphe sternum is contoured on either side by narrow undulated depression adjoining to striae.

Type :-Russia, Lake Baikal, the southern basin, the Cape Polovinnyj, epilithon, st. 44, $9 \mathrm{~m}$ depth, 22 June 1998, collector V. Votyakov (holotype: slide 0127-BK collection "Darwin initiative" housed at the Limnological Institute SB RAS, Irkutsk, Russia; isotype: slide 0127a-BK, ibid.).

Paraplaconeis interrupta Pomazkina \& Sherbakova sp. nov. (Pomazkina et al., 2018, p. 83, Table 125)

Valves wide, elliptic-lanceolate with attenuated rostrate ends. Length 36.6-41.1 $\mu \mathrm{m}$, width 17.3-18.0 $\mu \mathrm{m}$. Axial area wide, linear; central area small weakly transapically widened with shortened central striae. Striae radiate, biseriate, 9-10 in $10 \mu \mathrm{m}$. Raphe filiform, undulate, proximal endings with small pores slightly deflected oppositely, distal endings differently curved to the same side. Raphe sternum is contoured on either side by wide undulated depression adjoining to striae.

Type :-Russia, Lake Baikal, the northern basin, near the Cape Kabanij, epilithon, st. 22, $20 \mathrm{~m}$ depth, 04 July 1997, collector V. Votyakov (holotype: slide 0073-BK collection "Darwin initiative" housed at the Limnological Institute SB RAS, Irkutsk, Russia; isotype: slide 0074-BK, ibid.).

Paraplaconeis lacustris Pomazkina \& Sherbakova sp. nov. (Pomazkina et al., 2018, p. 83, Table 126)

Valves elliptic-lanceolate with weakly attenuated rostrate ends. Length $69.5-80.6 \mu \mathrm{m}$, width $17.8-22.6$ $\mu \mathrm{m}$. Axial area narrow at the apices widening to the middle of the valve; central area small, oval with shortened central striae. Striae radiate, biseriate, strongly radiate at the apices, 8-10 in $10 \mu \mathrm{m}$. Raphe filiform, proximal endings with pores slightly deflected to the same side, distal endings differently bent. Raphe sternum is contoured on either side by wide undulated depression adjoining to striae.

Type :-Russia, Lake Baikal, the southern basin, the Cape Polovinnyj, epilithon, st. 44, $9 \mathrm{~m}$ depth, 22 June 1998, collector V. Votyakov (holotype: slide 0127-BK collection "Darwin initiative" housed at the Limnological Institute SB RAS, Irkutsk, Russia; isotype: slide 0127a-BK, ibid.).

Paraplaconeis litoralis Pomazkina sp. nov. (Pomazkina et al., 2018, p. 84, Table 123)

Valve elliptic-lanceolate with attenuated rostrate ends. Length 93.6-101.0 $\mu \mathrm{m}$, width 33.6-41.1 $\mu \mathrm{m}$. Axial area narrow, linear; central area small oval transapically widened with shortened central striae. Striae radiate, uniseriate, becoming biseriate towards valve ends and the margin, 8-9 in $10 \mu \mathrm{m}$, at the apices 10 in $10 \mu \mathrm{m}$. Raphe filiform, linear with proximal pores, distal endings widely curved to the same side. Raphe sternum is contoured on either side by narrow depression adjoining to striae.

Type :-Russia, Lake Baikal, near the city of Baikalsk, silt, st. 40, 20 m depth, 23 June 1998, collector V. Votyakov (holotype: slide 0145-BK collection "Darwin initiative" housed at the Limnological Institute SB RAS, Irkutsk, Russia; isotype: slide 0146-BK, ibid.).

Paraplaconeis maculata Pomazkina \&

Sherbakova sp. nov. (Pomazkina et al., 2018, p. 85, Table 128)

Valve elliptic-lanceolate with attenuated rostrate ends. Length $44.0 \mu \mathrm{m}$, width $16.8 \mu \mathrm{m}$. Axial area narrow, linear widening to the middle of the valve; central area small transapically extended. Striae radiate, biseriate, 13-14 in $10 \mu \mathrm{m}$. Raphe filiform with narrow linear endings proximally, terminal fissures differently curved to the same side. Raphe sternum is contoured on either side by narrow depression adjoining to striae.

Type :-Russia, Lake Baikal, the northern basin, the Cape Orlovij, sand, st. 25, $12 \mathrm{~m}$ depth, 05 July 1997, collector V. Votyakov (holotype: slide 0083-BK collection "Darwin initiative" housed at the Limnological Institute SB RAS, Irkutsk, Russia; isotype: slide 0084-BK, ibid.).

Paraplaconeis magna Pomazkina \& Sherbakova sp. nov. (Pomazkina et al., 2018, p. 85, Table 129)

Valve elliptic-lanceolate with shortly attenuated rostrate ends. Length $62.5 \mu \mathrm{m}$, width $26.0 \mu \mathrm{m}$. Axial area narrow, linear gradually wider to the middle of the valve; central area small, oval, transapically extended with shortened central striae. Striae radiate, 8 in 10 $\mu \mathrm{m}$ becoming denser at the apices, 10 in $10 \mu \mathrm{m}$. Raphe filiform narrow, proximal endings with pores, terminal fissures differently bent to the same side. Raphe sternum is contoured on either side by depression adjoining to striae.

Type :-Russia, Lake Baikal, south basin, near the settlement Mangutaj, stones and silt, st. 41, $20 \mathrm{~m}$ depth, 22 June 1998, collector V. Votyakov (holotype: slide 0139-BK collection "Darwin initiative" housed at the Limnological Institute SB RAS, Irkutsk, Russia; isotype: slide 0139a-BK, ibid.).

Paraplaconeis propria Pomazkina sp. nov. (Pomazkina et al., 2018, p. 86, Table 130 )

Valves elliptic-lanceolate with slightly attenuated rostrate ends. Length 40.4-44.0 $\mu \mathrm{m}$, width 14-17.3 $\mu \mathrm{m}$. Axial area narrow, linear; central area small, oval, transapically extended with shortened central striae. Striae biseriate, radiate, 9-10 in $10 \mu \mathrm{m}$ becoming closer at the apices, 14-15 in $10 \mu \mathrm{m}$. Raphe filiform linear, proximal endings slightly expanded, terminal fissures curved to the same side. Raphe sternum is contoured on either side by depression wide undulated in the center, becoming narrow towards the apices.

Type :-Russia, Lake Baikal, the northern basin, near the Cape Kabanij, epilithon, st. 22, $20 \mathrm{~m}$ depth, 04 July 1997, collector V. Votyakov (holotype: slide 0073-BK collection "Darwin initiative" housed at the Limnological Institute SB RAS, Irkutsk, Russia; isotype: slide 0074-BK, ibid.).

Paraplaconeis recta Pomazkina \& Rodionova sp. nov. (Pomazkina et al., 2018, p. 86, Table 131)

Valve elliptic-lanceolate with attenuated capitate ends. Length $22.2 \mu \mathrm{m}$, width $6.7 \mu \mathrm{m}$. Axial area narrow, becoming gradually wider to the middle of the valve; central area small, rounded with shortened central striae. Striae biseriate, radiate, $14-15$ in $10 \mu \mathrm{m}$ becoming closer at the apices, 18-19 in $10 \mu \mathrm{m}$. Raphe filiform linear, proximal endings slightly expanded, terminal fissures bent to the same side. 
Type :-Russia, Lake Baikal, the northern basin, near the Cape Kabanij, epilithon, st. 22, $20 \mathrm{~m}$ depth, 04 July 1997, collector V. Votyakov (holotype: slide 0073-BK collection "Darwin initiative" housed at the Limnological Institute SB RAS, Irkutsk, Russia; isotype: slide 0074-BK, ibid.).

Paraplaconeis signum Pomazkina \& Rodionova sp. nov. (Pomazkina et al., 2018, p. 87, Table 132

Valve broad elliptic-lanceolate with weakly attenuated rostrate ends. Length $45.6 \mu \mathrm{m}$, width 18.3 $\mu \mathrm{m}$. Axial area narrow at the apices, slightly widening to the middle of the valve; central area slightly transapically extended with shortened central striae. Striae biseriate, radiate, $10-11$ in $10 \mu \mathrm{m}$ becoming closer near the apices, 12-13 in $10 \mu \mathrm{m}$. Raphe filiform linear, proximal endings with pores, endings slightly expanded, terminal fissures differently bent to the same side.

Type :-Russia, Lake Baikal, the southern basin, the Cape Polovinnyj, epilithon, st. 44, $9 \mathrm{~m}$ depth, 22 June 1998, collector V. Votyakov (holotype: slide 0127-BK collection "Darwin initiative" housed at the Limnological Institute SB RAS, Irkutsk, Russia; isotype: slide 0127a-BK, ibid.).

Paraplaconeis undulata Pomazkina \& Sherbakova sp. nov. (Pomazkina et al., 2018, p. 87, Table 133)

Valve broad elliptic-lanceolate with cuneate ends. Length $55.6 \mu \mathrm{m}$, width $23.0 \mu \mathrm{m}$. Axial area narrow near the apices becoming slightly wider towards the middle of the valve; central area almost indistinct weakly transapically extended with shortened central striae. Striae biseriate, radiate, 7-8 in $10 \mu \mathrm{m}$. Raphe filiform, proximal endings with oppositely bent pores, terminal fissures differently bent to the same side. Raphe sternum is contoured on either side by narrow depression adjoining to striae.

Type :-Russia, Lake Baikal, the southern basin, the Cape Polovinnyj, epilithon, st. 44, $9 \mathrm{~m}$ depth, 22 June 1998, collector V. Votyakov (holotype: slide 0127-BK collection "Darwin initiative" housed at the Limnological Institute SB RAS, Irkutsk, Russia; isotype: slide 0127c-BK, ibid.).

Paraplaconeis vernalis Pomazkina \& Sherbakova sp. nov. (Pomazkina et al., 2018, p. 88, Table 134)

Valves broad elliptic-lanceolate with shortly protracted cuneate ends. Length $69.9 \mu \mathrm{m}$, width 31.1 $\mu \mathrm{m}$. Axial area narrow near the apices becoming wider towards the middle of the valve; central area small transapically extended with shortened central striae. Striae biseriate, radiate, 7-8 in $10 \mu \mathrm{m}$, becoming closer towards the apices, 12-13 in $10 \mu \mathrm{m}$. Raphe filiform, proximal endings with oppositely bent pores, terminal fissures differently undulate to the same side.

Type :-Russia, Lake Baikal, the southern basin, the Cape Polovinnyj, epilithon, st. 44, $9 \mathrm{~m}$ depth, 22 June 1998, collector V. Votyakov (holotype: slide 0127-BK collection "Darwin initiative" housed at the Limnological Institute SB RAS, Irkutsk, Russia; isotype: slide 0127a-BK, ibid.).

\section{Genus Placoneis Mereschkowsky}

Placoneis abundans var. australis Pomazkina \& Rodionova var. nov. (Pomazkina et al., 2018, p. 91, Table 137)

Valves elliptic-lanceolate with protracted capitate ends. Length 27.9-32.0 $\mu \mathrm{m}$, width 10.7-12.0 $\mu \mathrm{m}$. Axial area narrow near the apices becoming slightly wider towards the small transversally extended central area with alternating short and long striae. One or more (up to four) round stigmata in the central area. Striae radiate, $12-13$ in $10 \mu \mathrm{m}$, becoming closer towards the apices, 16-17 in $10 \mu \mathrm{m}$. Raphe filiform, proximal endings slightly expanded, terminal raphe fissures differently undulated.

Type :-Russia, Lake Baikal, the southern basin, near the settlement Kultuk, epilithon, st. 42, $20 \mathrm{~m}$ depth, 22 June 1998, collector V. Votyakov (holotype: slide 0132-BK collection "Darwin initiative" housed at the Limnological Institute SB RAS, Irkutsk, Russia; isotype: slide 0133-BK, ibid.).

Placoneis abundans var. baicalensis Pomazkina \& Rodionova sp. nov. (Pomazkina et al., 2018, p. 92, Table 138)

Valves elliptic-lanceolate with protracted rostrate ends. Length 22.0-24.1 $\mu \mathrm{m}$, width 9.1-10.0 $\mu \mathrm{m}$. Axial area becoming gradually wider to the transapically extended central area with alternating short and long striae. Striae radiate, 13-14 in $10 \mu \mathrm{m}$, becoming closer towards the apices, 15-16 in $10 \mu \mathrm{m}$. Raphe filiform, proximal endings with pores, terminal raphe fissures arcuated. Two round stigmata in the central area.

Type :-Russia, Lake Baikal, the southern basin, near the settlement Kultuk, epilithon, st. 42, $20 \mathrm{~m}$ depth, 22 June 1998, collector V. Votyakov (holotype: slide 0132-BK collection "Darwin initiative" housed at the Limnological Institute SB RAS, Irkutsk, Russia; isotype: slide 0133-BK, ibid.).

Placoneis abyssalis Pomazkina \& Sherbakova sp. nov. (Pomazkina et al., 2018, p. 92, Table 139)

Valve elliptic-lanceolate with slightly protracted rounded ends. Length $23.3 \mu \mathrm{m}$, width $10.8 \mu \mathrm{m}$. Axial area narrow slightly widening to the small rounded central area with alternating short and long striae. Striae radiate, $14-15$ in $10 \mu \mathrm{m}$, becoming closer near the apices, 30 in $10 \mu \mathrm{m}$. Raphe filiform, proximal endings straight with pores, terminal raphe fissures widely curved to the same side. Isolated stigma absent.

Type :-Russia, Lake Baikal, south basin, near the settlement Mangutaj, stones and silt, st. 41, $20 \mathrm{~m}$ depth, 22 June 1998, collector V. Votyakov (holotype: slide 0138-BK collection "Darwin initiative" housed at the Limnological Institute SB RAS, Irkutsk, Russia; isotype: slide 0139-BK, ibid.).

Placoneis acuta Pomazkina \& Rodionova sp. nov. (Pomazkina et al., 2018, p. 93, Table 140)

Valves elliptic-lanceolate with cuneate ends. Length 45.8-47.1 $\mu \mathrm{m}$, width 16.2-17.1 $\mu \mathrm{m}$. Axial area narrow; central area small, insignificantly transapically widened with shortened central striae. Striae radiate, 5-6 in $10 \mu \mathrm{m}$. Raphe filiform, proximal endings with pores bent oppositely, terminal raphe fissures 
differently widely curved. Raphe sternum is contoured on either side by narrow depression adjoining to striae. Isolated stigma absent.

Type :-Russia. Lake Baikal, the Olkhon Gates Strait, epilithon, st. 7, 20 m depth, 27 June 1997, collectorV. Votyakov (holotype: slide 0017-BK collection "Darwin initiative" housed at the Limnological Institute SB RAS, Irkutsk, Russia; isotype: slide 0018-BK ibid.).

Placoneis argentata Pomazkina \& Sherbakova sp. nov. (Pomazkina et al., 2018, p. 93, Table 141)

Valves elliptic-lanceolate with protracted rostrate ends. Length 30.0-58.0 $\mu \mathrm{m}$, width 12.9-23.2 $\mu \mathrm{m}$. Axial area narrow, slightly widening to the small transapically extended central area with shortened central striae. Striae broad, slightly radiate in the center, strongly radiate near the apices, 6-11 in $10 \mu \mathrm{m}$. Raphe filiform, curved distally. Proximal raphe endings with pores bent oppositely, terminal fissures differently widely-curved. Raphe sternum is contoured on either side by narrow undulating depression adjoining to striae.

Type :-Russia, Lake Baikal, the northern basin, the Cape Velikan, epilithon, st. 23, $20 \mathrm{~m}$ depth, 04 July 1997, collector V. Votyakov (holotype: slide 0075-BK collection "Darwin initiative" housed at the Limnological Institute SB RAS, Irkutsk, Russia; isotype: slide 0076-BK, ibid.).

Placoneis attenuata Pomazkina \& Rodionova sp. nov. (Pomazkina et al., 2018, 94, Table 142)

Valve elliptic with cuneate rounded ends. Length $27.2 \mu \mathrm{m}$, width $17.4 \mu \mathrm{m}$. Axial area gradually widening to the small rounded central area with alternating short and long striae. Striae radiate, 10 in $10 \mu \mathrm{m}$, becoming closer towards the apices, 11 in $10 \mu \mathrm{m}$.

Raphe filiform, proximal raphe endings with pores bent oppositely, terminal fissures extending at the very raphe ends, widely-curved unilaterally. Isolated stigma absent.

Type :-Russia, Lake Baikal, the Olkhon Gates Strait, the Cape Otto-Khushin, epilithon, st. 53, $20 \mathrm{~m}$ depth, 25 June 1998, collector V. Votyakov (holotype: slide 0182-BK collection "Darwin initiative" housed at the Limnological Institute SB RAS, Irkutsk, Russia; isotype: slide 0182a-BK, ibid)

Placoneis betulina Pomazkina \& Rodionova sp. nov. (Pomazkina et al., 2018, 94, Table 143)

Valves elliptic-lanceolate with cuneate ends. Length 78.7-82.5 $\mu \mathrm{m}$, width 20.7-21.3 $\mu \mathrm{m}$. Axial area gradually widening to the rhombic insignificantly transversely extended central area with shortened striae. Striae weakly radiate in the center, 8-11 in 10 $\mu \mathrm{m}$, becoming closer towards the apices, 11-13 in 10 $\mu \mathrm{m}$. Raphe filiform, proximal endings with pores bent unilaterally, terminal fissures extending at the very raphe ends, widely-curved to the same side. Isolated stigma absent.

Type :-Russia, Lake Baikal, southern basin, near the settlement B. Koty, epilithon, st. 1, $20 \mathrm{~m}$ depth, 22 June 1997, collector V. Votyakov (holotype: slide 0001-BK collection "Darwin initiative" housed at the Limnological Institute SB RAS, Irkutsk, Russia; isotype: slide 0001a-BK ibid.).
Placoneis bona Pomazkina \& Sherbakova sp. nov. (Pomazkina et al., 2018, p. 95, Table 144)

Valves elliptic-lanceolate with attenuate rostrate ends. Length $25.8-27.0 \mu \mathrm{m}$, width $10.5-11.0 \mu \mathrm{m}$. Axial area narrow; central area small oval with alternating short and long striae. Striae strongly radiate, 16-19 in $10 \mu \mathrm{m}$. Raphe filiform, proximal endings with pores, terminal fissures widely-curved to the same direction as the central ends. Single stigma at the very end of one of the central striae.

Type :-Russia, Lake Baikal, the southern basin, near the settlement Kultuk, epilithon, st. 42, $20 \mathrm{~m}$ depth, 22 June 1998, collector V. Votyakov (holotype: slide 0132-BK collection "Darwin initiative" housed at the Limnological Institute SB RAS, Irkutsk, Russia; isotype: slide 0133-BK, ibid.).

Placoneis composita Pomazkina \& Sherbakova sp. nov. (Pomazkina et al., 2018, p. 95, Table 145)

Valves elliptic-lanceolate with sharp cuneate ends. Length 35.9-42.4 $\mu \mathrm{m}$, width 15.1-16.0 $\mu \mathrm{m}$. Axial area moderate; central area transversely extended with shortened striae. Striae radiate, 10-11 in $10 \mu \mathrm{m}$, becoming closer towards the apices, 12 in $10 \mu \mathrm{m}$. Raphe filiform, undulate distally. Proximal raphe endings with pores, terminal fissures long bent oppositely. Distinct raphe branch including the central pore is encircled on either side with the straight depression, excluding near the apices areas and not adjoined the striae. Isolated stigma absent.

Type :-Russia, Lake Baikal, near the city of Baikalsk, silt, st. 40, 20 m depth, 23 June 1998, collector V. Votyakov (holotype: slide 0145-BK collection "Darwin initiative" housed at the Limnological Institute SB RAS, Irkutsk, Russia; isotype: slide 0146-BK, ibid.).

Placoneis cruciata Pomazkina \& Rodionova sp. nov. (Pomazkina et al., 2018, p. 96, Table 146)

Valve elliptic with wide slightly protracted capitate ends. Length $13.9 \mu \mathrm{m}$, width $5.5 \mu \mathrm{m}$. Axial area narrow, linear; central area elliptic, transversely extended with shortened striae. Striae radiate, 18 in $10 \mu \mathrm{m}$. Raphe filiform, linear. Proximal raphe endings straight weakly expanded, terminal fissures widelycurved unilaterally.

Type :-Russia, Lake Baikal, Peschanaya Bay, small stones, st. 3, $20 \mathrm{~m}$ depth, 26 June1997, collector V. Votyakov (holotype: slide 0007-BK collection "Darwin initiative" housed at the Limnological Institute SB RAS, Irkutsk, Russia; isotype: slide 0008-BK ibid.).

Placoneis dahurica (Skvortzow) Pomazkina \& Rodionova comb. nov. (Pomazkina et al., 2018, p. 96, Table 147)

Basionym: Navicula dahurica Skvortzow 1937, p. 337, pl. 7, fig. 35, pl. 8, fig. 7.

Valves elliptic-lanceolate with slightly protracted rostrate ends. Length 48.0-49.1 $\mu \mathrm{m}$, width 20.0-21.0 $\mu \mathrm{m}$. Axial area narrow, linear; central area small, transversely extended with alternating short and long striae. Striae radiate, becoming strongly radiate towards the apices, 7-8 in $10 \mu \mathrm{m}$. Raphe filiform, linear. Proximal raphe endings with pores, terminal fissures differently curved unilaterally end with a small depression at the very raphe ending. 
Placoneis diaphana Pomazkina \& Rodionova sp. nov. (Pomazkina et al., 2018, p. 96, Table 148)

Valve elliptic-lanceolate with cuneate ends. Length $20.9 \mu \mathrm{m}$, width $9.6 \mu \mathrm{m}$. Axial area narrow near the apices becoming gradually wider towards the small rounded central area with alternating short and long striae. Striae radiate, 14 in $10 \mu \mathrm{m}$ becoming closer towards the apices, 18 in $10 \mu \mathrm{m}$. Raphe filiform, linear. Proximal raphe endings with pores, terminal fissures fine, differently curved unilaterally. One rounded stigma in the central area.

Type :-Russia, Lake Baikal, the northern basin, the Cape Velikan, stones, st. 23, $20 \mathrm{~m}$ depth, 04 July 1997, collector V. Votyakov (holotype: slide 0075 collection "Darwin initiative" housed at the Limnological Institute SB RAS, Irkutsk, Russia; isotype: slide 0076, ibid.).

Placoneis distincta Pomazkina \& Sherbakova sp. nov. (Pomazkina et al., 2018, p. 97, Table 149)

Valve elliptic-lanceolate with slightly protracted rostrate ends. Length $43.3 \mu \mathrm{m}$, width $13.8 \mu \mathrm{m}$. Axial area narrow, becoming gradually wider towards the transversely elliptical central area with some shortened striae. Striae radiate, 14 in $10 \mu \mathrm{m}$, becoming closer towards the apices, 18 in $10 \mu \mathrm{m}$. Raphe filiform, uneven. Proximal raphe endings with pores bent oppositely to the curved terminal fissures.

Type :-Russia, Lake Baikal, Anga Bay, silt and sand, st. 6, $17 \mathrm{~m}$ depth, 27 June 1997, collector V. Votyakov (holotype: slide 0014-BK collection "Darwin initiative" housed at the Limnological Institute SB RAS, Irkutsk, Russia; isotype: slide 0015-BK ibid.).

Placoneis elenae Pomazkina \& Sherbakova sp. nov. (Pomazkina et al., 2018, p. 97, Table 150)

Valve elliptic-lanceolate with cuneate ends. Length $41.1 \mu \mathrm{m}$, width $20.0 \mu \mathrm{m}$. Axial area narrow, gradually widening towards the transversely extended central area with alternating short and long striae. Striae wide, radiate, 17 in $10 \mu \mathrm{m}$, becoming closer near the apices, 18 in $10 \mu \mathrm{m}$. Raphe filiform, linear, then curved closer to the apices. Proximal raphe endings with pores bent oppositely; terminal fissures fine, differently curved unilaterally. One rounded stigma in the central area.

Type :-Russia, Lake Baikal, the southern basin, near the settlement Kultuk, epilithon, st. 42, $20 \mathrm{~m}$ depth, 22 June 1998, collector V. Votyakov (holotype: slide 0132-BK collection "Darwin initiative" housed at the Limnological Institute SB RAS, Irkutsk, Russia; isotype: slide 0133-BK, ibid.).

Placoneis elenae var. undata Pomazkina \& Sherbakova var. nov. (Pomazkina et al., 2018, p. 98, Table 151)

Valve elliptic-lanceolate with cuneate ends. Length $33.6 \mu \mathrm{m}$, width $18.0 \mu \mathrm{m}$. Axial area narrow gradually widening towards the transversely elliptical central area with alternating short and long striae. Striae wide, radiate, 8 in $10 \mu \mathrm{m}$, becoming closer near the apices, 9 in $10 \mu \mathrm{m}$. Raphe filiform, closer to the apices uneven. Proximal raphe endings with pores, terminal fissures differently curved to the same side. Isolated stigma absent.
Type :-Russia, Lake Baikal, the southern basin, near the settlement Kultuk, epilithon, st. 42, 20 m depth, 22 June 1998, collector V. Votyakov (holotype: slide 0132-BK collection "Darwin initiative" housed at the Limnological Institute SB RAS, Irkutsk, Russia; isotype: slide 0133-BK, ibid.).

Placoneis eugeniae Sherbakova sp. nov. (Pomazkina et al., 2018, p. 98, Table 152)

Valves wide elliptic-lanceolate with cuneate rounded ends. Length 35.0-44.4 $\mu \mathrm{m}$, width 20.7-25.4 $\mu \mathrm{m}$. Axial area narrow at the apices widening towards the transversely elliptical central area with alternating short and long striae. Striae radiate, $7-8$ in $10 \mu \mathrm{m}$, becoming closer near the apices, 10-11 in $10 \mu \mathrm{m}$. Raphe filiform, becoming curved closer to the apices. Proximal raphe endings with pores, terminal fissures differently bent to the same side. Isolated stigma absent. Distinct raphe branch including the central pore is encircled on either side with the straight depression, excluding near the apices areas, and not adjoined the striae.

Type :-Russia. Lake Baikal, the Olkhon Gates Strait, epilithon, st. 7, 20 m depth, 27 June 1997, collectorV.Votyakov (holotype: slide 0017-BK collection "Darwin initiative" housed at the Limnological Institute SB RAS, Irkutsk, Russia; isotype: slide 0017a-BK ibid.).

Placoneis extraordinaris Pomazkina \& Rodionova sp. nov. (Pomazkina et al., 2018, p. 99,

Table 153)

Valves elliptic-lanceolate with cuneate rounded ends. Length 15.3-17.5 $\mu \mathrm{m}$, width $6.8-7.5 \mu \mathrm{m}$. Axial area narrow linear continuously widening into the small transversely extended central area with shortened central striae. Striae radiate, $14-15$ in $10 \mu \mathrm{m}$. Raphe filiform, linear. Proximal raphe endings with pores, terminal fissures differently curved unilaterally. Isolated stigma absent

Type :-Russia, Lake Baikal, the southern basin, near the settlement Kultuk, epilithon, st. 42, $20 \mathrm{~m}$ depth, 22 June 1998, collector V. Votyakov (holotype: slide 0132-BK collection "Darwin initiative" housed at the Limnological Institute SB RAS, Irkutsk, Russia; isotype: slide 0133-BK, ibid.).

Placoneis gelegma var. baicalensis Pomazkina \& Rodionova var. nov. (Pomazkina et al., 2018, p. 100, Table 155)

Valves elliptic-lanceolate with cuneate ends. Length 21.2-33.2 $\mu \mathrm{m}$, width 8.6-13.2 $\mu \mathrm{m}$. Axial area narrow linear continuously widening towards the small oval slightly transversely extended central area with alternating short and long striae. Striae wide, radiate, 10 in $10 \mu \mathrm{m}$, becoming closer near the apices, $18-20$ in $10 \mu \mathrm{m}$. Raphe filiform, linear. Proximal raphe endings with pores, terminal fissures differently curved unilaterally. Isolated stigma absent.

Type :-Russia, Lake Baikal, the southern basin, near the settlement Kultuk, epilithon, st. 42, $20 \mathrm{~m}$ depth, 22 June 1998, collector V. Votyakov (holotype: slide 0132-BK collection "Darwin initiative" housed at the Limnological Institute SB RAS, Irkutsk, Russia; isotype: slide 0133-BK, ibid.).

Placoneis granum Pomazkina \& Sherbakova sp. nov. (Pomazkina et al., 2018, p. 100, Table 156) 
Valve narrow elliptic-lanceolate with attenuate rostrate ends. Length $46.2 \mu \mathrm{m}$, width $16.2 \mu \mathrm{m}$. Axial area narrow continuously widening towards the small transversely extended central area with alternating short and long striae. Striae radiate, 10 in $10 \mu \mathrm{m}$, becoming closer and strongly radiate near the apices, 14 in $10 \mu \mathrm{m}$. Raphe filiform, linear. Proximal raphe endings with pores, terminal fissures differently curved unilaterally. Three round stigmata in the central area.

Type :-Russia, Lake Baikal, the southern basin, near the settlement Kultuk, epilithon, st. 42, $20 \mathrm{~m}$ depth, 22 June 1998, collector V. Votyakov (holotype: slide 0132-BK collection "Darwin initiative" housed at the Limnological Institute SB RAS, Irkutsk, Russia; isotype: slide 0132a-BK, ibid.).

Placoneis grata Pomazkina sp. nov. (Pomazkina et al., 2018, p. 101, Table 157)

Valves elliptic with rounded ends. Length 22.1$23.0 \mu \mathrm{m}$, width 10.7-11.0 $\mu \mathrm{m}$. Axial area narrow linear; central area small oval, the central stria more distant from neighboring striae. Striae radiate, 10-12 in $10 \mu \mathrm{m}$, becoming closer near the apices, 15-16 in $10 \mu \mathrm{m}$. Raphe filiform, linear. Proximal raphe endings with pores, terminal fissures bent unilaterally. One elongated stigmoid at the end of one of central striae.

Type :-Russia, Lake Baikal, the southern basin, near the settlement Kultuk, epilithon, st. 42, $20 \mathrm{~m}$ depth, 22 June 1998, collector V. Votyakov (holotype: slide 0132-BK collection "Darwin initiative" housed at the Limnological Institute SB RAS, Irkutsk, Russia; isotype: slide 0132a-BK, ibid.).

Placoneis ignita Pomazkina \& Sherbakova sp. nov. (Pomazkina et al., 2018, p. 101, Table 158)

Valves elliptic-lanceolate with protracted capitate ends. Length 26.0-28.4 $\mu \mathrm{m}$, width 10.3-11.0 $\mu \mathrm{m}$. Axial area narrow slightly widening towards the small insignificantly transversely extended central area with alternating short and long striae. Striae radiate, 13-15 in $10 \mu \mathrm{m}$. Raphe filiform. Proximal raphe endings with pores, terminal fissures differently curved unilaterally. One round stigma in the central area.

Type :-Russia, Lake Baikal, the southern basin, near the settlement Kultuk, epilithon, st. 42, $20 \mathrm{~m}$ depth, 22 June 1998, collector V. Votyakov (holotype: slide 0132-BK collection "Darwin initiative" housed at the Limnological Institute SB RAS, Irkutsk, Russia; isotype: slide 0132a-BK, ibid.).

Placoneis insularis Sherbakova \& Pomazkina sp. nov. (Pomazkina et al., 2018, p. 102, Table 159)

Valves elliptic-lanceolate with slightly protracted rostrate ends. Length 35.5-36.2 $\mu \mathrm{m}$, width 14.5-15.0 $\mu \mathrm{m}$. Axial area narrow slightly widening towards the transversely extended central area with alternating short and long striae. Striae radiate, 9-10 in $10 \mu \mathrm{m}$, becoming weakly radiate and closer near the apices, 12-13 in $10 \mu \mathrm{m}$. Raphe filiform. Proximal raphe endings with pores, terminal fissures curved unilaterally. One small round stigma in the central area.

Type :-Russia, Lake Baikal, the Olkhon Gates Strait, epilithon, st. 7, $20 \mathrm{~m}$ depth, 27 June 1997, collectorV. Votyakov (holotype: slide 0017-BK collection "Darwin initiative" housed at the Limnological Institute
SB RAS, Irkutsk, Russia; isotype: slide 0017a-BK ibid.).

Placoneis ivanii Pomazkina \& Rodionova sp. nov. (Pomazkina et al., 2018, p. 102, Table 160)

Valves elliptic-lanceolate with rounded cuneate ends. Length 17.3-19.6 $\mu \mathrm{m}$, width 10.3-10.4 $\mu \mathrm{m}$. Axial area narrow slightly widening towards the transversely extended central area with alternating short and long striae. Striae radiate, 13-14 in $10 \mu \mathrm{m}$. Raphe filiform. Proximal raphe endings with pores, terminal fissures differently bent unilaterally. One small round stigma is present in the central area.

Type :-Russia, Lake Baikal, Anga Bay, silt and sand, st. 6, $17 \mathrm{~m}$ depth, 27 June 1997, collector V. Votyakov (holotype: slide 0014-BK collection "Darwin initiative" housed at the Limnological Institute SB RAS, Irkutsk, Russia; isotype: slide 0015-BK ibid.).

Placoneis linearis Pomazkina \& Sherbakova sp. nov. (Pomazkina et al., 2018, p. 103, Table 161)

Valves linear-lanceolate with protracted rostrate ends. Length 37.2-38.0 $\mu \mathrm{m}$, width 13.0-13.5 $\mu \mathrm{m}$. Axial area narrow near apices, widening towards the transversely extended central area with shortened central striae. Striae radiate, 13-14 in $10 \mu \mathrm{m}$, becoming closer near the apices, 15-16 in $10 \mu \mathrm{m}$. Raphe filiform, straight. Proximal raphe endings with pores, terminal fissures curved unilaterally. Isolated stigma absent.

Type :-Russia, Lake Baikal, the southern basin, near the settlement Kultuk, epilithon, st. 42, $20 \mathrm{~m}$ depth, 22 June 1998, collector V. Votyakov (holotype: slide 0132-BK collection "Darwin initiative" housed at the Limnological Institute SB RAS, Irkutsk, Russia; isotype: slide 0146-BK, ibid.).

Placoneis ludmilae Pomazkina \& Sherbakova sp. nov. (Pomazkina et al., 2018, p. 103, Table 162)

Valves elliptic-lanceolate with rounded ends. Length 46.0-50.0 $\mu \mathrm{m}$, width 23.1-22.6 $\mu \mathrm{m}$. Axial area moderate near apices, widening towards the rounded transversely extended central area with shortened central striae. Striae radiate to strongly radiate, in the center 7-9 in $10 \mu \mathrm{m}$, becoming closer near the apices, 9-10 in $10 \mu \mathrm{m}$. Raphe filiform, straight. Proximal raphe endings slit-like or with very small pores, terminal fissures fine differently bent to the same side then completed with little triangle depression. Isolated stigma absent.

Type :-Russia, Lake Baikal, south basin, near the settlement Mangutaj, stones and silt, st. 41, $20 \mathrm{~m}$ depth, 22 June 1998, collector V. Votyakov (holotype: slide 0138-BK collection "Darwin initiative" housed at the Limnological Institute SB RAS, Irkutsk, Russia; isotype: slide 0139-BK, ibid.).

Placoneis magna Pomazkina \& Sherbakova sp. nov. (Pomazkina et al., 2018, p. 104, Table 163)

Valve elliptic-lanceolate with protracted rostrate ends. Length $67.7 \mu \mathrm{m}$, width $30.6 \mu \mathrm{m}$. Axial area narrow slightly becoming wider towards the rounded transversely extended central area with alternating short and long striae. Striae radiate, spaced, 6-7 in 10 $\mu \mathrm{m}$. Raphe filiform, uneven. Proximal raphe endings with T-shaped pores, terminal fissures differently bent unilaterally. Isolated stigma absent.

Type :-Russia, Lake Baikal, the southern basin, 
near the settlement Kultuk, epilithon, st. 42, $20 \mathrm{~m}$ depth, 22 June 1998, collector V. Votyakov (holotype: slide 0132-BK collection "Darwin initiative" housed at the Limnological Institute SB RAS, Irkutsk, Russia; isotype: slide 0132c-BK, ibid.).

Placoneis mira Pomazkina \& Rodionova sp. nov. (Pomazkina et al., 2018, p. 104, Table 165)

Valves elliptic-lanceolate with protracted capitate ends. Length 25.0-27.0 $\mu \mathrm{m}$, width 9.0-9.7 $\mu \mathrm{m}$. Axial area narrow; central area small transversely extended with alternating short and long striae. Striae strongly radiate, $15-16$ in $10 \mu \mathrm{m}$, becoming closer near the apices, 18 in $10 \mu \mathrm{m}$. Raphe filiform, linear. Proximal raphe endings with pores, terminal fissures differently bent unilaterally. Isolated stigma absent.

Type :-Russia, Lake Baikal, the southern basin, near the settlement Kultuk, epilithon, st. 42, $20 \mathrm{~m}$ depth, 22 June 1998, collector V. Votyakov (holotype: slide 0132-BK collection "Darwin initiative" housed at the Limnological Institute SB RAS, Irkutsk, Russia; isotype: slide 0132c-BK, ibid.).

Placoneis mollis Pomazkina \& Rodionova sp. nov. (Pomazkina et al., 2018, p. 105, Table 167)

Valves elliptic-lanceolate with slightly protracted cuneate ends. Length 23.0-24.0 $\mu \mathrm{m}$, width 7.0-9.0 $\mu \mathrm{m}$. Axial area narrow; central area small insignificantly transversely extended with alternating short and long striae. Striae radiate, 14-15 in $10 \mu \mathrm{m}$, becoming closer near the apices, 19-20 in $10 \mu \mathrm{m}$. Raphe filiform, linear. Proximal raphe endings with pores, terminal fissures differently bent unilaterally. One stigma in the central area.

Type :-Russia, Lake Baikal, the southern basin, near the settlement Kultuk, epilithon, st. 42, $20 \mathrm{~m}$ depth, 22 June 1998, collector V. Votyakov (holotype: slide 0132-BK collection "Darwin initiative" housed at the Limnological Institute SB RAS, Irkutsk, Russia; isotype: slide 0132c-BK, ibid.).

Placoneis navicula Pomazkina \& Sherbakova sp. nov. (Pomazkina et al., 2018, p. 106, Table 168)

Valve elliptic-lanceolate with protracted rostrate ends. Length $46.9 \mu \mathrm{m}$, width $19.1 \mu \mathrm{m}$. Axial area narrow; central area small transversely extended with shortened central striae. Striae radiate, $7-8$ in $10 \mu \mathrm{m}$. Raphe filiform, linear. Proximal raphe endings slightly widened, terminal fissures differently curved unilaterally. Isolated stigma absent.

Type :-Russia, Lake Baikal, the Cape Krestovskij, stones and silt, st. 5, $20 \mathrm{~m}$ depth, 27 June1997, collector V. Votyakov (holotype: slide 0011-BK collection "Darwin initiative" housed at the Limnological Institute SB RAS, Irkutsk, Russia; isotype: slide 0012-BK ibid.).

Placoneis paragelegma Pomazkina \& Rodionova sp. nov. (Pomazkina et al., 2018, p. 106, Table 169)

Valves elliptic-lanceolate with slightly protracted rostrate ends. Length 21.4-23.0 $\mu \mathrm{m}$, width 7.8-8.0 $\mu \mathrm{m}$. Axial area narrow slightly widening to the small insignificantly transversely extended central area with alternating short and long striae. Striae radiate, 12-13 in $10 \mu \mathrm{m}$, becoming closer near the apices, $15-16$ in 10 $\mu \mathrm{m}$. Raphe filiform, linear. Proximal raphe endings with pores, terminal fissures differently curved unilaterally. One stigma in the central area.

Type :-Russia, Lake Baikal, the Olkhon Gates Strait, the Cape Otto-Khushin, epilithon, st. 53, $20 \mathrm{~m}$ depth, 25 June 1998, collector V. Votyakov (holotype: slide 0183-BK collection "Darwin initiative" housed at the Limnological Institute SB RAS, Irkutsk, Russia; isotype: slide 0182-BK, ibid).

Placoneis parvula Pomazkina \& Rodionova sp. nov. (Pomazkina et al., 2018, p. 107, Table 171)

Valves elliptic with protracted capitate ends. Length 16.6-18.0 $\mu \mathrm{m}$, width 6.3-6.5 $\mu \mathrm{m}$. Axial area narrow linear slightly widening to the small insignificantly transversely extended central area with alternating short and long striae. Striae radiate, 16 in $10 \mu \mathrm{m}$. Raphe filiform, linear. Proximal raphe endings with pores, terminal fissures differently curved unilaterally. One stigma inon the central area.

Type :-Russia, Lake Baikal, the southern basin, near the settlement Kultuk, epilithon, st. 42, $20 \mathrm{~m}$ depth, 22 June 1998, collector V. Votyakov (holotype: slide 0132-BK collection "Darwin initiative" housed at the Limnological Institute SB RAS, Irkutsk, Russia; isotype: slide 0132a-BK, ibid.).

Placoneis paucimarensis Rodionova \& Pomazkina sp. nov. (Pomazkina et al., 2018, p. 108, Table 172)

Valves elliptic-lanceolate with slightly protracted rostrate ends. Length 24.1-27.0 $\mu \mathrm{m}$, width 10.0-11.0 $\mu \mathrm{m}$. Axial area narrow linear; the central area small, oval insignificantly transversely extended central area with alternating short and long striae. Striae strongly radiate, $12-13$ in $10 \mu \mathrm{m}$. Raphe filiform, linear. Proximal raphe endings with pores, terminal fissures differently curved unilaterally. An elongated stigmoid at the end of the central shortened stria.

Type :-Russia, Lake Baikal, the Olkhon Gates Strait, the Cape Khara-Khulun, epilithon, st. 51, $20 \mathrm{~m}$ depth, 25 June 1998, collector V. Votyakov (holotype: slide 0176-BK collection "Darwin initiative" housed at the Limnological Institute SB RAS, Irkutsk, Russia; isotype: slide 0177-BK, ibid).

Placoneis radialis Pomazkina \& Rodionova sp. nov. (Pomazkina et al., 2018, p. 108, Table 173)

Valves elliptic-lanceolate with slightly protracted rostrate ends. Length 24.2-27.6 $\mu \mathrm{m}$, width 9.3-10.0 $\mu \mathrm{m}$. Axial area narrow slightly widening to the small transversely extended central area with alternating short and long striae. Striae radiate, 13-15 in $10 \mu \mathrm{m}$, becoming strongly radiate and closer near the apices, 18-24 in $10 \mu \mathrm{m}$. Raphe filiform, undulated near the apices. Proximal raphe endings with pores, terminal fissures differently rounded to the same side. Two or more (up to 5) of small round stigmata in the central area.

Type :-Russia, Lake Baikal, the southern basin, near the settlement Kultuk, epilithon, st. 42, $20 \mathrm{~m}$ depth, 22 June 1998, collector V. Votyakov (holotype: slide 0132-BK collection "Darwin initiative" housed at the Limnological Institute SB RAS, Irkutsk, Russia; isotype: slide 0132a-BK, ibid.).

Placoneis radialis var. producta Pomazkina \& 
Rodionova var. nov. (Pomazkina et al., 2018, p. 109, Table 174)

Valves elliptic-lanceolate with protracted rostrate ends. Length 29.8-38.4 $\mu \mathrm{m}$, width 8.3-12.3 $\mu \mathrm{m}$. Axial area narrow slightly widening to the small transversely extended central area with alternating short and long striae. Striae radiate, $12-17$ in $10 \mu \mathrm{m}$, becoming strongly radiate and closer near the apices, 20-25 in $10 \mu \mathrm{m}$. Raphe filiform, undulated near the apices. Proximal raphe endings straight with pores, terminal fissures differently curved to the same side. Two or more stigmata (up to 7) of small round stigmata in the central area.

Type :-Russia, Lake Baikal, the southern basin, near the settlement Kultuk, epilithon, st. 42, $20 \mathrm{~m}$ depth, 22 June 1998, collector V. Votyakov (holotype: slide 0132-BK collection "Darwin initiative" housed at the Limnological Institute SB RAS, Irkutsk, Russia; isotype: slide 0132a-BK, ibid.).

Placoneis regionalis Pomazkina \& Sherbakova sp. nov. (Pomazkina et al., 2018, p. 109, Table 175)

Valve elliptic-lanceolate with cuneate rounded ends. Length $31.9 \mu \mathrm{m}$, width $19.3 \mu \mathrm{m}$. Axial area narrow; the central area small oval, transversely extended with shortened striae. Striae radiate, 9-10 in $10 \mu \mathrm{m}$. Raphe filiform, linear. Proximal raphe endings with elongated teardrop-shaped pores, terminal fissures differently curved unilaterally. Raphe sternum is contoured on either side by narrow deep depression interrupted near the central and apical areas, adjoining to striae.

Type :-Russia, Lake Baikal, the Olkhon Gates Strait, epilithon, st. 7, $20 \mathrm{~m}$ depth, 27 June 1997, collectorV. Votyakov (holotype: slide 0017-BKcollection "Darwin initiative" housed at the Limnological Institute SB RAS, Irkutsk, Russia; isotype: slide 0017a-BK ibid.).

Placoneis rhombea Pomazkina \& Rodionova sp. nov. (Pomazkina et al., 2018, p. 110, Table 176)

Valve rhombic with cuneate rounded ends. Length $16.6 \mu \mathrm{m}$, width $8.2 \mu \mathrm{m}$. Axial area narrow, linear; the central area small, transversely extended with alternating short and long striae. Striae radiate, 14 in $10 \mu \mathrm{m}$. Raphe filiform, linear. Proximal raphe endings straihgt, terminal fissures differently curved unilaterally.

Type :-Russia, Lake Baikal, Peschanaya Bay, small stones, st. 3, 20 m depth, 26 June1997, collector V. Votyakov (holotype: slide 0007-BK collection "Darwin initiative" housed at the Limnological Institute SB RAS, Irkutsk, Russia; isotype: slide 0007a-BK ibid.).

Placoneis septentrionalis Pomazkina \& Rodionova sp. nov. (Pomazkina et al., 2018, p. 110, Table 178)

Valve wide elliptic-lanceolate with shortly protracted rostrate ends. Length $40.7 \mu \mathrm{m}$, width 18.6 $\mu \mathrm{m}$. Axial area broad; the central area small nearly indistinct with shortened striae. Striae radiate, 8-9 in $10 \mu \mathrm{m}$, becoming closer near the apices, 14-15 in 10 $\mu \mathrm{m}$. Raphe filiform, slightly undulate. Proximal raphe endings with pores, terminal fissures differently curved unilaterally.

Type :-Russia, Lake Baikal, northern basin, near the Cape Elokhin, epilithon, st. 12, $20 \mathrm{~m}$ depth,
29 June 1997, collector V. Votyakov (holotype: slide 0040-BK collection "Darwin initiative" housed at the Limnological Institute SB RAS, Irkutsk, Russia; isotype: slide 0041-BK, ibid.).

Placoneis simplex Pomazkina \& Rodionova sp. nov. (Pomazkina et al., 2018, p. 111, Table 179)

Valves elliptic with cuneate widely rounded ends. Length 16.9-18.0 $\mu \mathrm{m}$, width 8.2-9.0 $\mu \mathrm{m}$. Axial area narrow, linear; the central area small transversely extended with alternating short and long striae. Striae radiate, $14-15$ in $10 \mu \mathrm{m}$. Raphe filiform, linear. Proximal raphe endings with elongated teardrop-shaped pores, terminal fissures differently curved unilaterally.

Type :-Russia, Lake Baikal, Peschanaya Bay, small stones, st. 3, $20 \mathrm{~m}$ depth, 26 June1997, collector V. Votyakov (holotype: slide 0007-BK collection "Darwin initiative" housed at the Limnological Institute SB RAS, Irkutsk, Russia; isotype: slide 0007a-BK ibid.).

Placoneis solaris Pomazkina, Rodionova \& Sherbakova sp. nov. (c. 111, Table 180)

Valves elliptic-lanceolate with more or less protracted rostrate ends. Length 23.1-25.0 $\mu \mathrm{m}$, width 8.1-9.0 $\mu \mathrm{m}$. Axial area narrow slightly widening to the small nearly transversely extended central area with alternating short and long striae. Striae radiate, in the center12 in $10 \mu \mathrm{m}$, becoming closer near the apices, 20 in $10 \mu \mathrm{m}$. Raphe filiform, linear. Proximal raphe endings with pores slightly bent in the same direction as the differently curved terminal fissures. Round small stigma in the central area.

Type :-Russia, Lake Baikal, Anga Bay, silt and sand, st. 6, $17 \mathrm{~m}$ depth, 27 June 1997, collector V. Votyakov (holotype: slide 0014-BK collection "Darwin initiative" housed at the Limnological Institute SB RAS, Irkutsk, Russia; isotype: slide 0015-BK ibid.).

Placoneis vadosa Pomazkina \& Rodionova sp. nov. (Pomazkina et al., 2018, p. 112, Table 181)

Valves elliptic-lanceolate with protracted capitate ends. Length 15.6-17.8 $\mu \mathrm{m}$, width 7.2-8.0 $\mu \mathrm{m}$. Axial area narrow; the central area small, weakly transversely extended with alternating short and long striae. Striae radiate, 14-16 in $10 \mu \mathrm{m}$. Raphe filiform, linear. Proximal raphe endings with pores, terminal fissures widely rounded unilaterally.

Type :-Russia, Lake Baikal, the Olkhon Gates Strait, the Cape Otto-Khushin, epilithon, st. 53, $20 \mathrm{~m}$ depth, 25 June 1998, collector V. Votyakov (holotype: slide 0183-BK collection "Darwin initiative" housed at the Limnological Institute SB RAS, Irkutsk, Russia; isotype: slide 0182-BK, ibid)

Placoneis vladimiri Pomazkina sp. nov. (Pomazkina et al., 2018, p. 112, Table 182)

Valve elliptic-lanceolate with cuneate ends. Length $45.0 \mu \mathrm{m}$, width $19.7 \mu \mathrm{m}$. Axial area narrow; the central area small, transversely extended with shortened striae. Striae radiate, 8-9 in $10 \mu \mathrm{m}$. Raphe filiform, linear at the center, becoming uneven closer to apices. Proximal raphe endings with pores, terminal fissures differently curved unilaterally.

Type :-Russia, Lake Baikal, Anga Bay, silt and sand, st. 6, $17 \mathrm{~m}$ depth, 27 June 1997, collector V. Votyakov (holotype: slide 0014-BK collection "Darwin 
initiative" housed at the Limnological Institute SB RAS, Irkutsk, Russia; isotype: slide 0015-BK ibid.).

Placoneis vladimiri var. diminuta Pomazkina var. nov. (Pomazkina et al., 2018, p. 113, Table 183)

Valves elliptic-lanceolate with cuneate ends. Length 35.0-37.0 $\mu \mathrm{m}$, width 19.0-19.7 $\mu \mathrm{m}$. Axial area wide; the central area rounded, transversely extended with alternating short and long striae. Striae radiate, 8-9 in $10 \mu \mathrm{m}$. Raphe filiform, uneven. Proximal raphe endings with pores, terminal fissures differently curved unilaterally.

Type :-Russia, Lake Baikal, Anga Bay, silt and sand, st. 6, $17 \mathrm{~m}$ depth, 27 June 1997, collector V. Votyakov (holotype: slide 0014-BK collection "Darwin initiative" housed at the Limnological Institute SB RAS, Irkutsk, Russia; isotype: slide 0015-BK ibid.).

Placoneis witkowskii var. baicalensis Pomazkina \& Sherbakova var. nov. (Pomazkina et al., 2018, p. 113, Table 184)

Valves elliptic-lanceolate with protracted capitate ends. Length 16.1-18.0 $\mu \mathrm{m}$, width 4.2-7.0 $\mu \mathrm{m}$. Axial area narrow; the central area nearly transversely extended with alternating short and long striae. Striae radiate, $16-17$ in $10 \mu \mathrm{m}$. Raphe filiform, uneven. Proximal raphe endings with pores, terminal fissures differently curved unilaterally.

Type :-Russia, Lake Baikal, the Olkhon Gates Strait, the Cape Otto-Khushin, epilithon, st. 53, $20 \mathrm{~m}$ depth, 25 June 1998, collector V. Votyakov (holotype: slide 0183-BK collection "Darwin initiative" housed at the Limnological Institute SB RAS, Irkutsk, Russia; isotype: slide 0184-BK, ibid.).

\section{Genus Polygonaria Rodionova, Pomazkina \& Sherbakova gen.nov.}

Type generic: Polygonaria wislouchii (Skvortzow \& Meyer) Rodionova, Pomazkina \& Sherbakova comb. nov. (Pomazkina et al., 2018, p. 115, Table 186)

Cells biraphid, "naviculoid". Characters of the chloroplast is not yet known. Valves isopolar, widelylinear. Valve ends slightly protracted, cuneate. External axial area wide; the central area oval, asymmetrically expended. Raphe filiform, weakly lateral. Proximal raphe endings with hooks bent in one direction. Terminal fissures rounded unilaterally. Striae punctated, parallel in the center, becoming slightly radial towards apices, composed of rounded to transapically widened oval areolae, irregularly arranged in the striae. Internally, proximal raphe endings slit-like, subtly bent unilaterally, distal raphe endings with helictoglossae. Areolae in striae also irregular, rounded to oval, open.

Polygonaria wislouchii (Skvortzow \& Meyer) Rodionova, Pomazkina \& Sherbakova comb. nov. (Pomazkina et al., 2018, p. 115, Table 186)

Basionym: Navicula wislouchii Skvortzow \& Meyer 1928, p. 20, pl. 1, fig.72.

Valves widely-linear with slightly protracted, cuneate ends. Length 61.0-81.0 $\mu \mathrm{m}$, width 16.8$20.7 \mu \mathrm{m}$. Axial area wide; the central area nearly indistinct, asymmetrically expended. Raphe filiform, weakly lateral. Proximal raphe endings hooked, bent in one direction. Terminal fissures both rounded in the side opposite to the side the proximal endings bent. Areolae irregular in striae forming uneven hyaline lines on the valve surface. Striae punctated, parallel in the valve center, becoming radial towards apices, 11-13 in $10 \mu \mathrm{m}$.

\section{Acknowledgements}

We are very grateful to Wolf-Henning Kusber for his valuable help in preparing this article. This work was supported by the project 345-2019-0001 FASO Russia.

\section{References}

Cleve P.T. 1895. Synopsis of the naviculoid diatoms. Kongliga Svenska Vetenskaps-Akademiens Handlingar [Royal Swedish Academy of Sciences Documents] 27: 1-219.

Grunow A. 1860. Über neue oder ungenügend gekannte Algen. Erste Folge, Diatomeen, Familie Naviculaceen. Verhandlungen der Kaiserlich-Königlichen ZoologischBotanischen Gesellschaft [Negotiations of the Imperial-Royal Zoological-Botanical Society] 10: 503-582. (In German)

Pomazkina G.V., Rodionova E.V., Sherbakova T.A. 2018. Benthic diatom algae of the family Naviculaceae of Lake Baikal. Novosibirsk: Nauka. (In Russian)

Skabitchevsky A.P. 1936. New and interesting diatoms from the Northern Baikal. Botanicheskiy Zhurnal SSSR [Botanical Journal of the USSR] 21: 705-719. (In Russian)

Skvortzow B.W. 1937. Bottom diatoms from Olhon Gate of Baikal Lake, Siberia. Philippine Journal of Science 62: 293-377.

Skvortzow B.W., Meyer C.I. 1928. A contribution to the diatoms of Lake Baikal. Proceedings of the Sungaree River Biological Station 1: 1-55.

International code of nomenclature for algae, fungi, and plants (Shenzhen Code) adopted by the Nineteenth International Botanical Congress Shenzhen, China, July 2017. Regnum Vegetabile 159. 2018. In: Turland N.J., Wiersema J.H., Barrie F.R., Greuter W., Hawksworth D.L., Herendeen P.S., Knapp S., Kusber W.-H., Li D.-Z., Marhold K., May T.W., McNeill J., Monro A.M., Prado J., Price M.J., Smith G.F. (Eds.). Glashütten: Koeltz Botanical Books. DOI: doi.org/10.12705/ Code. 2018 